\title{
Computer-Aided Modelling and Analysis of PV Systems: A Comparative Study
}

\author{
Charalambos Koukouvaos, ${ }^{1,2}$ Dionisis Kandris, ${ }^{3}$ and Maria Samarakou ${ }^{4}$ \\ ${ }^{1}$ School of Engineering and Physical Sciences, Heriot Watt University, Edinburgh EH14 1AS, UK \\ ${ }^{2}$ Central Greece Energy Distribution Administration, Public Power Corporation S.A., 34500 Aliveri, Greece \\ ${ }^{3}$ Department of Electronic Engineering, School of Technological Applications, Technological Educational Institute of Athens, \\ 12210 Athens, Greece \\ ${ }^{4}$ Department of Energy Technology Engineering, School of Technological Applications, Technological Educational Institute of Athens, \\ 12210 Athens, Greece
}

Correspondence should be addressed to Dionisis Kandris; dkandris@teiath.gr

Received 31 August 2013; Accepted 9 October 2013; Published 2 January 2014

Academic Editors: A. J. N. Khalifa and R. Maceiras

Copyright (c) 2014 Charalambos Koukouvaos et al. This is an open access article distributed under the Creative Commons Attribution License, which permits unrestricted use, distribution, and reproduction in any medium, provided the original work is properly cited.

\begin{abstract}
Modern scientific advances have enabled remarkable efficacy for photovoltaic systems with regard to the exploitation of solar energy, boosting them into having a rapidly growing position among the systems developed for the production of renewable energy. However, in many cases the design, analysis, and control of photovoltaic systems are tasks which are quite complex and thus difficult to be carried out. In order to cope with this kind of problems, appropriate software tools have been developed either as standalone products or parts of general purpose software platforms used to model and simulate the generation, transmission, and distribution of solar energy. The utilization of this kind of software tools may be extremely helpful to the successful performance evaluation of energy systems with maximum accuracy and minimum cost in time and effort. The work presented in this paper aims on a first level at the performance analysis of various configurations of photovoltaic systems through computer-aided modelling. On a second level, it provides a comparative evaluation of the credibility of two of the most advanced graphical programming environments, namely, Simulink and LabVIEW, with regard to their application in photovoltaic systems.
\end{abstract}

\section{Introduction}

Serious economic concerns along with the growing worries about the disastrous effects that technological progress accumulatively causes to world environment, impose a shift towards renewable energy resources, which constitute an environmental friendly approach for power generation with satisfactory efficiency [1]. That is why in many regions of the globe there is an official tendency to let renewable energy sources have an increasing share in the overall power production process. For instance, European Union, by means of the implementation of the so-called 20/20/20 initiative, aims to achieve by year 2020 not only the reduction of greenhouse gas emissions by $20 \%$ (compared to 1990 ones), but also the increase of the magnitude of renewable energy to
$20 \%$ and the decrease of the overall energy consumption by $20 \%$ through efficient energy management [2].

The renewable energy resources which have the most enhanced exploitation, thanks to relevant advances in modern scientific research, are solar, hydropower, geothermal, biomass, and wind energy $[3,4]$.

Solar energy refers to the solar radiation that reaches the Earth and can be converted into other forms of energy, such as heat and electricity. The transformation of solar radiation into electric current is performed by using photovoltaic (PV) cells. A PV cell is practically a p-n junction placed in the interior of a thin wafer of semiconductor. The solar radiation falling on a PV cell can be diconverted to electricity through the so-called photovoltaic effect. This is a physical phenomenon in which photons of light excite electrons into higher energy 
states letting them act as charge carriers for electric current. Specifically, the exposure of a PV to sunlight triggers the creation of electron-hole pairs proportional to the incident irradiation by photons having energy greater than the bandgap energy of the semiconductor material of the PV cell.

Over the last decades, the international interest in the PV conversion of solar radiation is continuously growing. In this way, the use of PV systems is nowadays widespread to an extent that is considered to constitute the third greater renewable energy source in terms of globally installed capacity, after hydro- and wind power.

On the other hand, the brilliant prospects of PV systems for further evolution get obstructed due to various technical and economic issues that have yet to be resolved. For this reason modern scientific and technological research focuses on the development of methodologies and equipment for the increase of energy efficiency of PV systems, the reduction of their production cost, the improvement of their market penetration, and the enhancement of their environmental performance [5-7].

These research activities can be greatly assisted by the utilization of software tools for the development of models of the PV systems under consideration and the analysis of their performance by carrying out simulation tests.

The aim of this paper is to perform the computer-aided design and performance analysis of both grid-connected and standalone PV systems by using in parallel the two most widely used graphical programming environments, namely, Simulink by Mathworks and LabVIEW by National Instruments. This task is accomplished by taking advantage of the potential provided through the adaptation of these two software platforms to systems of PV nature. The parallel utilization of MATLAB and LabVIEW enables the comparative evaluation of their accuracy, validity, and their overall performance under various simulation scenarios. According to the knowledge of the authors of this paper, this is the first comparative study of this kind which is performed in the field of photovoltaics, although similar studies have been carried out in other scientific areas such as [8].

The rest of the paper is organized as follows: Section 2 focuses on related work in the computer-assisted modelling of PV systems. Section 3 describes the procedures used for the PV systems modelling. In Section 4 the results of the simulation tests executed are presented. The discussion of these results is performed in Section 5. Finally, Section 6 concludes the paper.

\section{Computer-Aided Performance Analysis of PV Systems}

The performance of PV plant is subject to many parameters, the influence of which should be accurately estimated before any investment is made for the establishment of this plant. Actually, the temperature and solar radiation are the two main factors affecting the performance of PV systems. Specifically, ambient temperature should definitely be taken into consideration because the relationship between the temperature and the efficiency of solar cells is inversely proportional
[9]. Additionally, the energy produced by a PV system on an annual basis is directly related to the available solar radiation and therefore depends on the geographical location of the system because two radiation beams of equal power but of different wavelength can produce different amounts of electricity in a solar cell and thus form a different degree of performance [9]. Moreover, the operational efficiency of a solar panel may be affected by other environmental or other type factors such as the speed and direction of wind, the distribution of the solar spectrum, rain, shading, pollution, panel aging, optical losses, and panel casualties [9-13].

In order to calculate the energy efficiency of PV systems in an accurate and systematic modern research works focus on the computer-aided design and analysis of this type of systems [14].

For instance, a PV array simulation model incorporated in Simulink GUI environment was developed using basic circuit equations of the PV solar cells including the effects of solar irradiation and temperature changes. The developed model was tested by means of both a directly coupled DC load and an AC load via an inverter [15].

In another work a model for a solar PV array (PV), with an $\mathrm{AC} / \mathrm{DC}$ converter and load, a maximum power point tracker, a battery, and a charger, was built. The whole model was simulated under four testing scenarios some of which included cloudy and sunny conditions along with constant and varying load [16].

Similarly, an approach to determine the characteristic of a particular PV cell panel and to study the influence of different values of solar radiation at different temperatures concerning performance of PV cells in Simulink was proposed [17]. There are research works, such as [18], which focus on modelling and simulation of standalone PV systems, whilst others, like [19], address modelling and simulation of grid-connected PV systems to analyze the grid interface behavior and control performance in the system design. Other works, such as [20], predict energy production from PV panels under various performance conditions.

In [21] a generalized PV model built in MATLAB/ Simulink, which enables the simulation of the system dynamics, is presented. Similarly, [22] focuses on the modelling process of PV cells in Simulink while in [23] the two-diode model of PV module is examined.

Concentrating on educational applications, [24] describes the design and implementation of a virtual laboratory for PV power systems based on the Cadence PSpice circuit simulator. In [25] an integrated PV monitoring system having a graphical user interface developed in LabVIEW is presented.

\section{Theoretical Background}

The procedure of building accurate PV models is extremely important in order to achieve high efficiency in the decision making related to establishment and operation of PV systems. This justifies why, as already discussed in Section 2, many research works are carried out in this scientific area.

Generally, modelling of PV systems is based on the assumption that the operation of PV cells may be simulated 


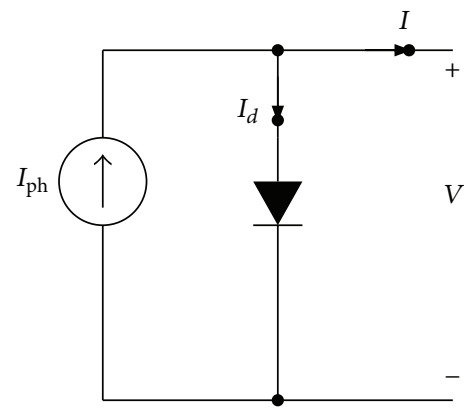

FIGURE 1: Electronic circuit equivalent to the model of an ideal PV cell.

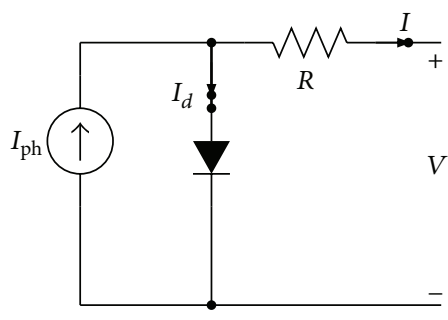

Figure 2: Electronic circuit representing a one-diode with serial resistance model of PV cell.

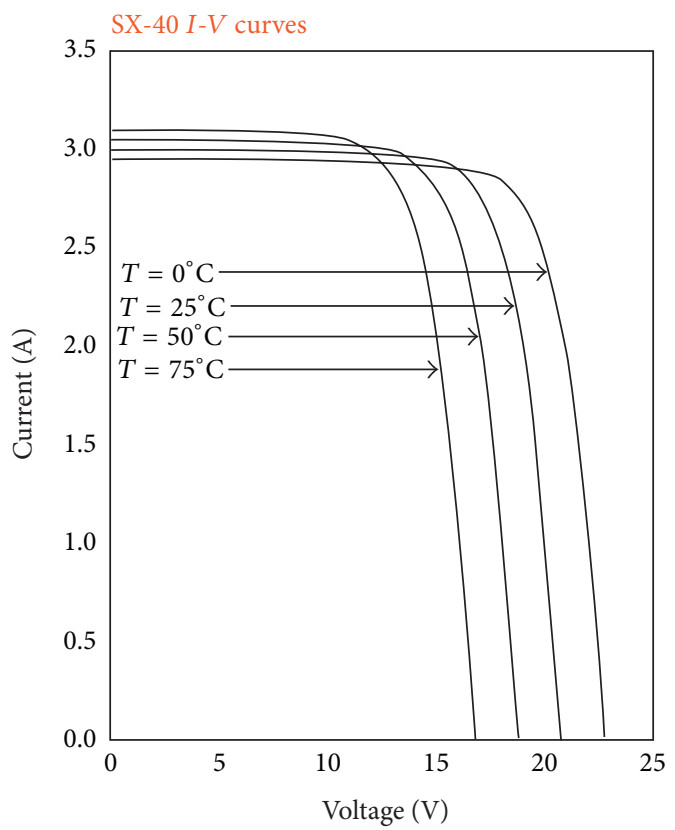

Figure 3: Characteristic $I-V$ curve of an SX-50 PV panel.

by examining the operation of analogous electronic circuits. The simplest PV model found in bibliography comprises a single diode connected in parallel with a light generated current source $\left(I_{\mathrm{ph}}\right)$ as shown in Figure 1 , where $I_{d}$ expresses the diode current $[26,27]$. This simplified model refers to an ideal solar cell.

Going one step further, a series resistance $R_{s}$, representing an internal parasitic resistance which reduces the efficiency of

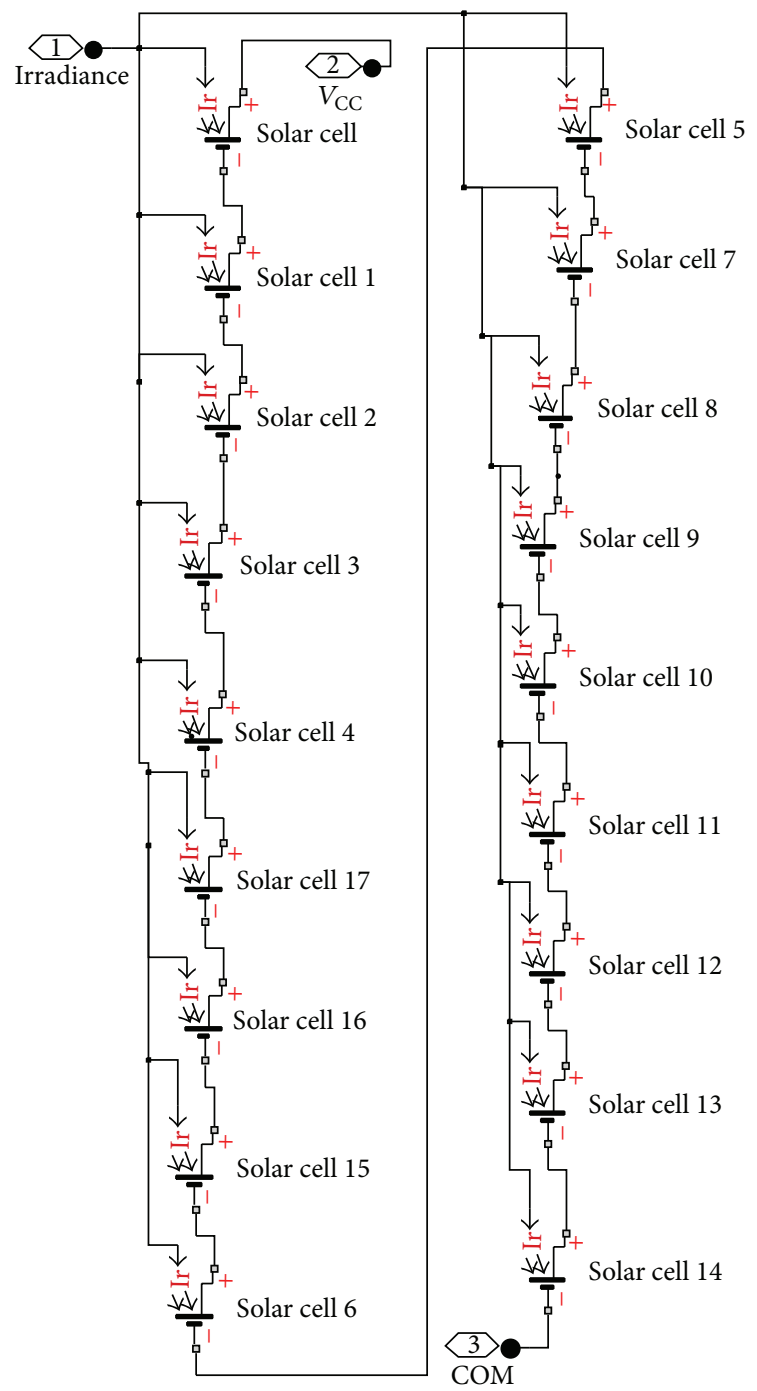

FIGURE 4: Overview of an SX-50 PV panel in Simulink.

the solar cell, is added to the circuit, as depicted in Figure 2 $[28,29]$. The relationship between the voltage and the current for a given temperature and solar radiation is given as

$$
I=I_{\mathrm{ph}}-I_{d}=I_{\mathrm{ph}}-I_{0} \cdot\left(e^{\left(V+I \cdot R_{s}\right) /\left(a \cdot V_{T}\right)}-1\right),
$$



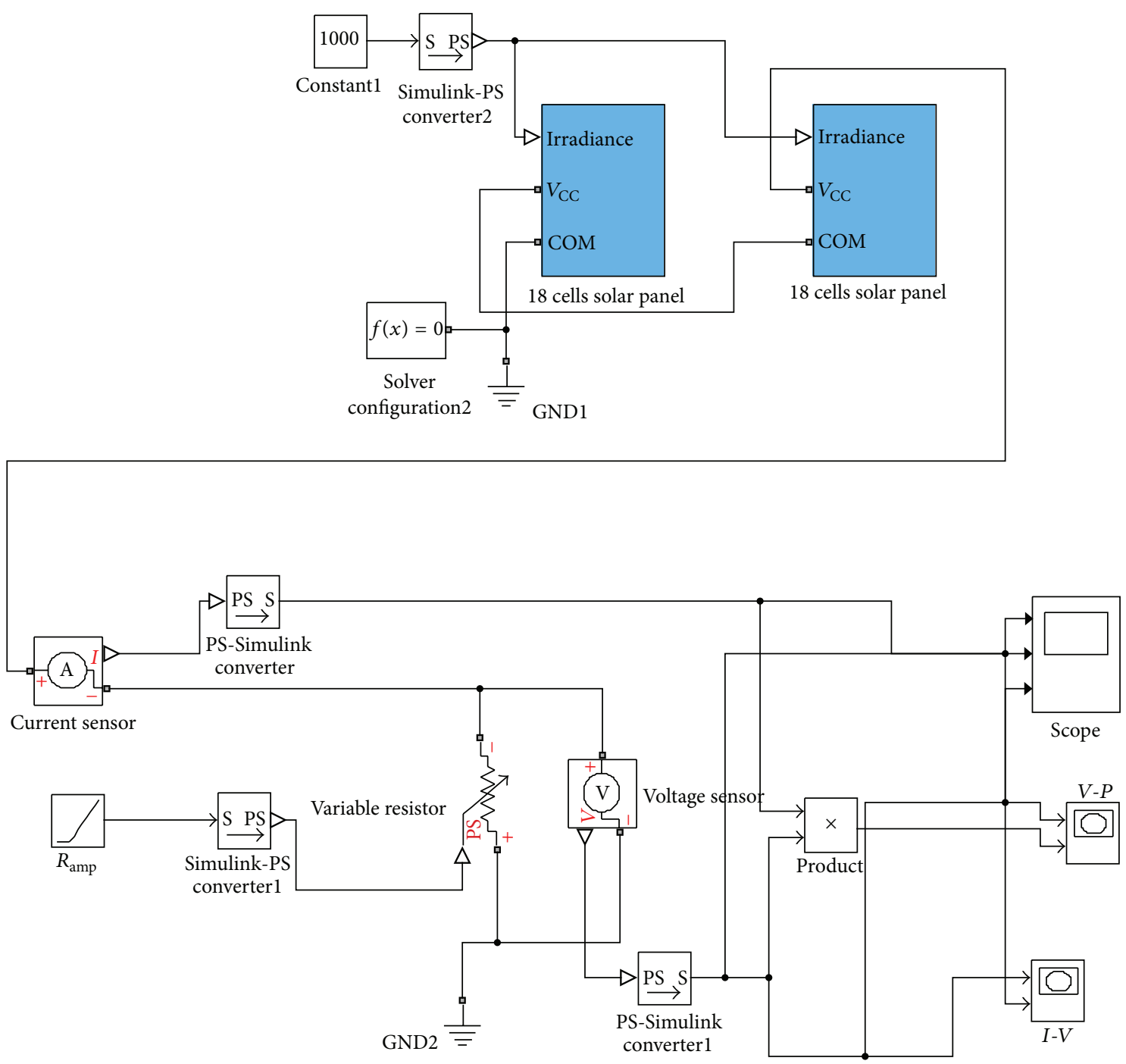

FIGURE 5: Simulation model of an SX-50 panel in Simulink.

where $I_{0}$ expresses the diode reverse saturation current, $a$ represents the ideality factor of the diode, and $V_{T}$ stands for the so-called thermal voltage of the PV module which is given by [2]

$$
V_{T}=\frac{N_{s} \cdot k \cdot T_{c}}{q}
$$

where $N_{s}$ denotes the number of photovoltaic cells connected in series in the PV module, $k$ stands for Boltzmann's constant $\left(1.3806503 \cdot 10^{-23} \mathrm{~J} / \mathrm{K}\right), T_{c}$ indicates the temperature of the photovoltaic cell (expressed in Kelvin degrees), and $q$ symbolizes the elementary electric charge $\left(1.60217646 \cdot 10^{-19} \mathrm{C}\right)$.

Other scientific researches make use of a model which is derived by the addition of shunt resistance $R_{p}$ in parallel to the diode in order to improve model accuracy in the cases of high variations of temperature and low voltage but in expense of complexity [30, 31].

A few research works adopt an ever more complex model, known as the two-diode model aiming to take into consideration recombination losses, that is, the elimination of mobile electrons and electron holes due to the existence of impurities or defects at the front or/and the rear surfaces of a cell. This model includes a second diode placed in parallel to the current source and the initial diode, thus calling for the simultaneous calculation of seven parameters based on either iteration approaches or more analytical methodologies [23].

When simulating a PV module, no matter which model is adopted, the goal is to calculate the $I-V$ and $P-V$ curves which are representative of the module operation. In this curve the so-called maximum power point (MPP) is determined as the point for which the power dissipated to the load is maximum. From basic circuit theory, the power delivered from or to a device is maximized where the derivative (graphically, the slope) $d I / d V$ of the $I-V$ curve is equal to and opposite of the $I / V$ ratio (where $d P / d V=0$ ) and corresponds to the "knee" of the curve.

Another technical feature that is taken into consideration during the simulation tests performed is the so-called total harmonic distortion (THD). Generally, THD of a signal is 


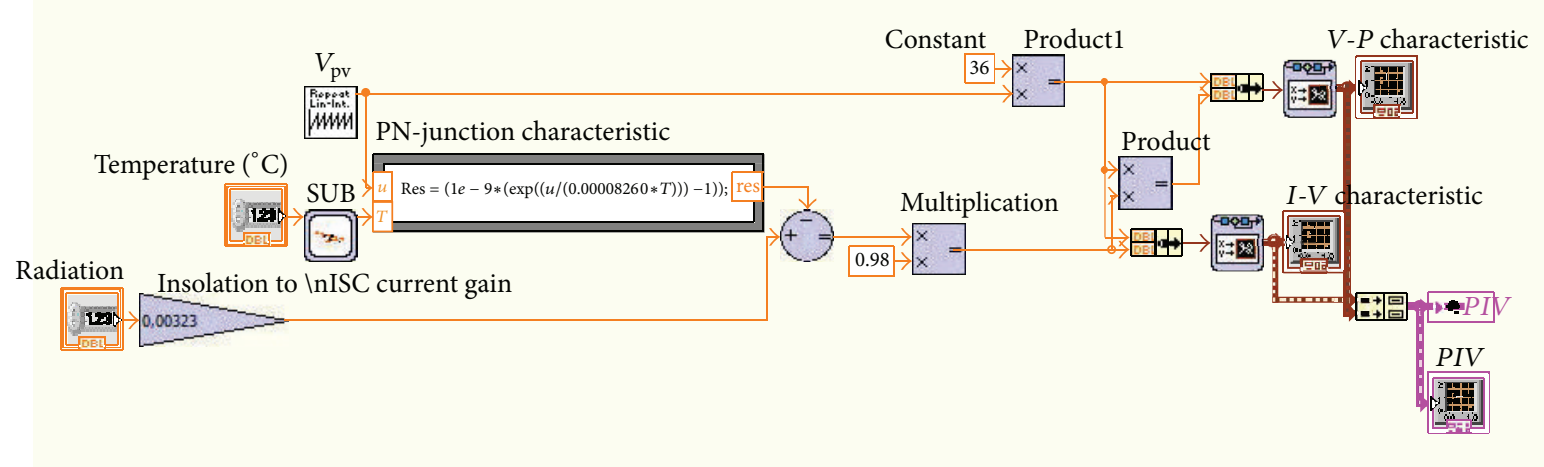

FIgURE 6: Simulation model of an SX-50 panel in LabVIEW.

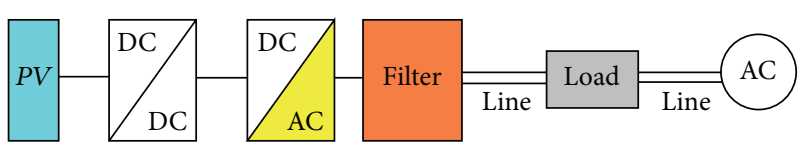

Figure 7: Overview of the integrated PV system modeled.

a measurement of the harmonic distortion present and is defined as the ratio of the sum of the powers of all harmonic components to the power of the fundamental frequency. In energy systems THD is used to characterize their power quality of electric power.

Finally, in order to carry out the comparative performance analysis of the modelling accuracy of Simulink and Labview the so called coefficient of determination was calculated. This is a statistic term denoted as $R^{2}$, which expresses the proportion of total variation of outcomes explained by a model, thus, providing a measure of how well-observed outcomes are replicated by this model.

\section{Modeling and Simulation Setup}

In accordance with the aforementioned, in Section 2, PV modelling studies the research work presented in this paper investigates the computer-aided modelling and analysis of first a standalone commercially available solar panel, second an integrated PV system without grid connection, and third a grid-connected PV system under low and high load conditions.

4.1. Modeling of a PV Panel. The first modelling procedure performed refers to the modelling and performance analysis of a single PV panel for the production of $I-V$ and $P-V$ curves in maximum power point (MPP). The modelling was performed both in Simulink and LabVIEW based on the aforementioned, in Section 3, one-diode with serial resistance PV model, because it has an adequate ratio of accuracy to complexity.

The specific PV panel examined is Solarex SX-50. The characteristic features of this PV panel along with their typical values, for solar irradiance $S=1000 \mathrm{~W} / \mathrm{m}^{2}$ and operation temperature $T=25^{\circ} \mathrm{C}$, are presented in Table 1 , while the
TABLE 1: Technical features of SX-50 PV panel.

\begin{tabular}{lc}
\hline Feature & Value \\
\hline Maximum power $\left(P_{\max }\right)$ & $50 \mathrm{~W}$ \\
Voltage at $P_{\max }\left(V_{\max }\right)$ & $16.8 \mathrm{~V}$ \\
Current at $P_{\max }\left(I_{\max }\right)$ & $2.97 \mathrm{~A}$ \\
Guaranteed minimum $P_{\max }$ & $45 \mathrm{~W}$ \\
Short-circuit current $\left(I_{\mathrm{sc}}\right)$ & $3.23 \mathrm{~A}$ \\
Temperature coefficient of $I_{\text {sc }}$ & $(0.065 \pm 0.015) \% /{ }^{\circ} \mathrm{C}$ \\
Temperature coefficient of $V_{\mathrm{oc}}$ & $-(80 \pm 10) \mathrm{mV} /{ }^{\circ} \mathrm{C}$ \\
Temperature coefficient of power & $-(0.5 \pm 0.05) \% /{ }^{\circ} \mathrm{C}$ \\
\hline
\end{tabular}

$I-V$ curve for various operating temperatures is illustrated in Figure 3. The specific panel consists of 36 photovoltaic silicon cells located in two rows of $18 \mathrm{PV}$ cells each. The modelling of SX-50 PV panel in Simulink was performed by using Simscape-SimElectronics library. Figure 4 shows that the structure of the PV panel consisted of two sets of 18 cells each. The corresponding simulation model built is depicted in Figure 5. The modelling of SX-50 PV panel in LabVIEW was performed by using NI LabVIEW Simulation Interface Toolkit. Figure 6 shows the resultant model developed.

4.2. Modeling of an Integrated PV System with No Grid Connection. The second modelling procedure performed refers to the modelling and performance analysis of a typical integrated PV system, consisting of a PV energy source, a DC/DC converter, a DC/AC inverter, a filter, and a load as shown in Figure 7.

The modelling was performed both in Simulink and LabVIEW based on the assumptions that the power of the photovoltaic generator is equal to $4.6 \mathrm{KW}$ and the operation temperature is set to $25^{\circ} \mathrm{C}$. Additionally, solar irradiance is supposed to have a stable value equal to $1000 \mathrm{~W} / \mathrm{m}^{2}$ while the load magnitude is equal to $2 \mathrm{KW}$. The system was connected to a low-voltage grid by using alternatively a low load (1.5 KW) or a high load (6.5 KW).

The filter is an LC circuit aiming to cut off the range of the output current which produces the DC-AC inverter harmonic frequencies. Similarly, an RL circuit was incorporated in the line that connects the filter with the load. Figure 8 


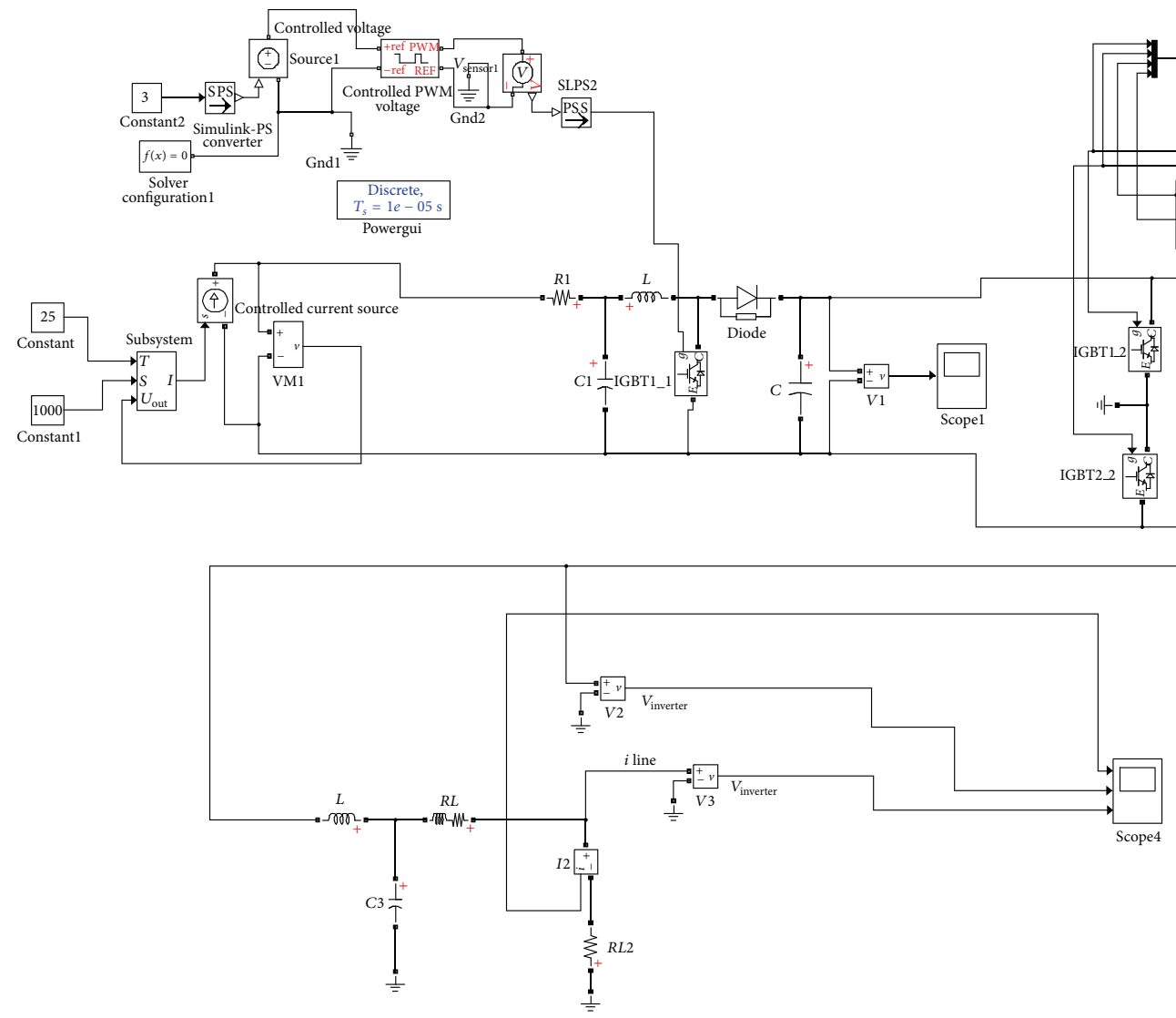

FIGURE 8: Integrated PV system model in Simulink.

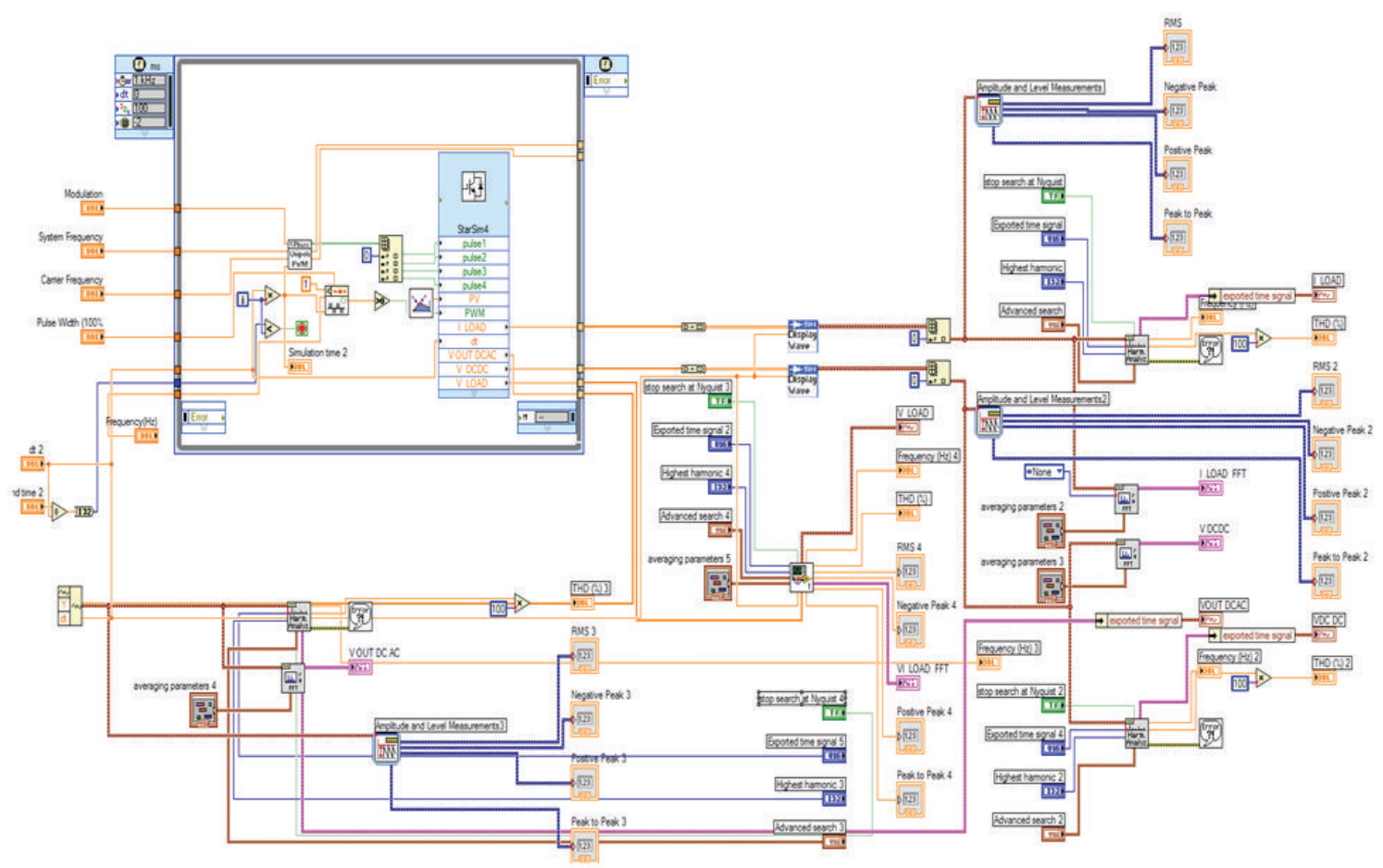

FIGURE 9: Integrated PV system model in LabVIEW. 


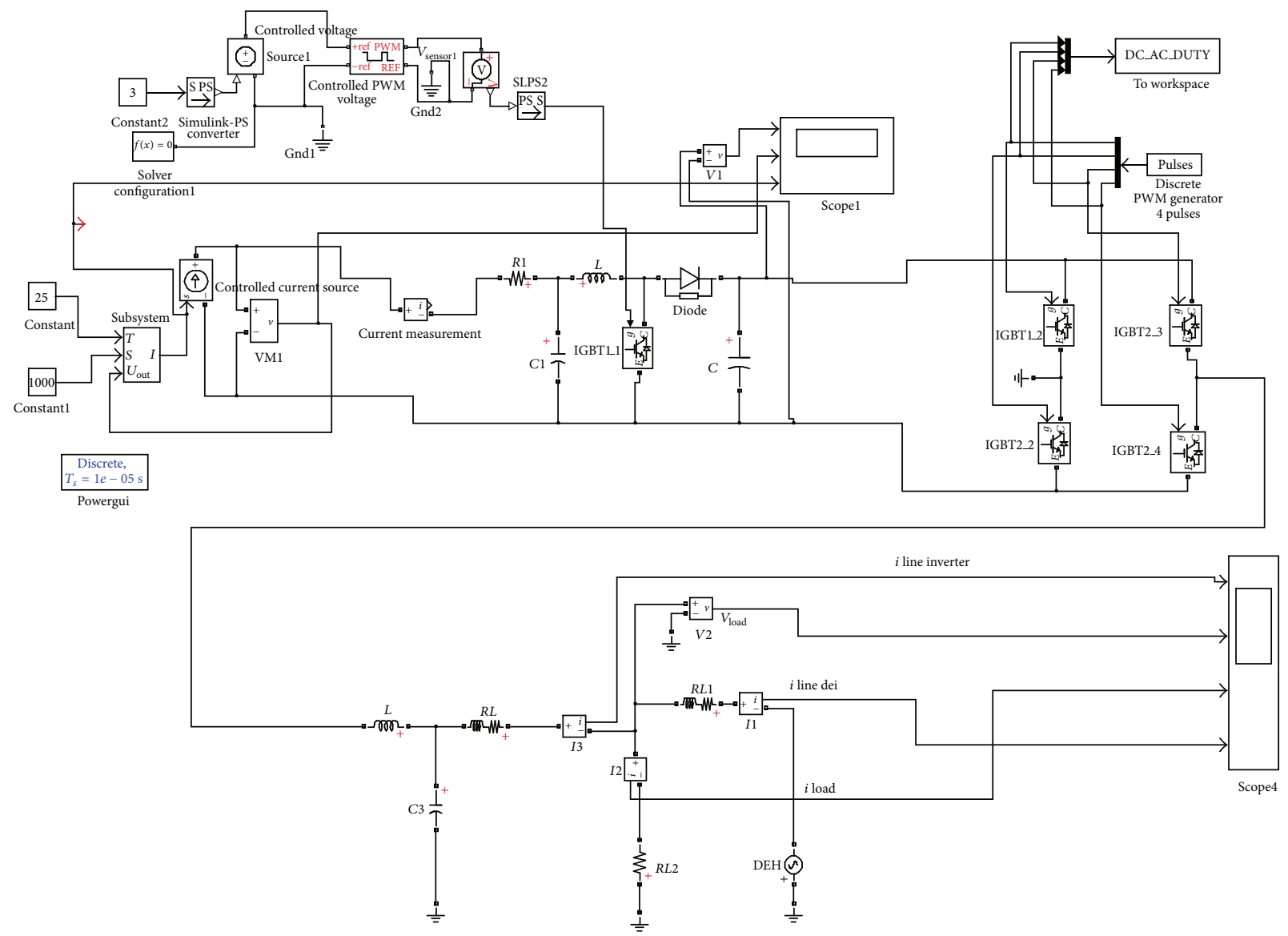

FIgURE 10: Grid-connected integrated PV system model in Simulink.

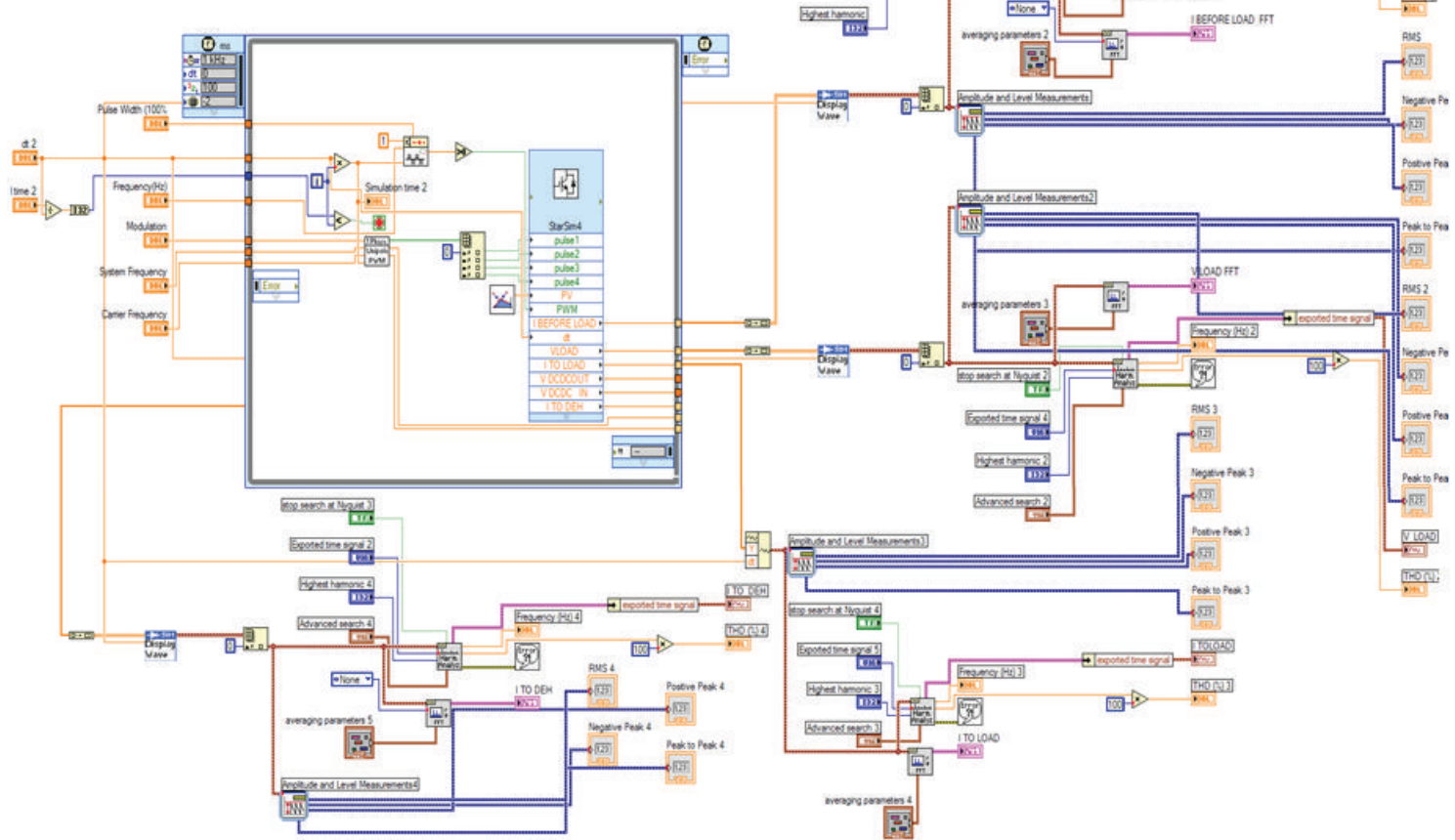

FIGURE 11: Grid-connected integrated PV system model in LabVIEW. 


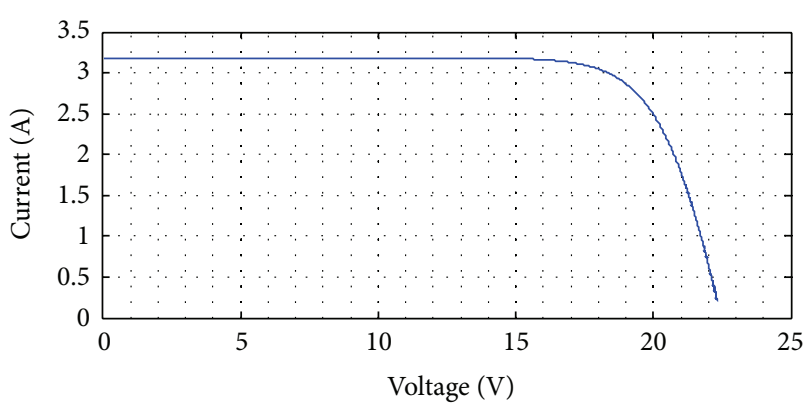

(a)

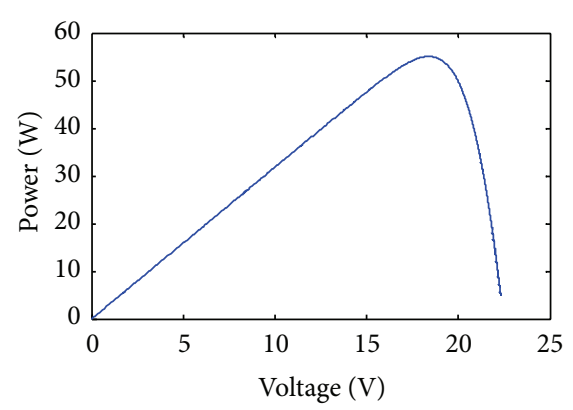

(b)

FIgURe 12: $I-V$ and $P-V$ curves for SX-50 Solarex PV panel when $T=25^{\circ} \mathrm{C}$ and $S=1000 \mathrm{~W} / \mathrm{m}^{2}$ in Simulink.

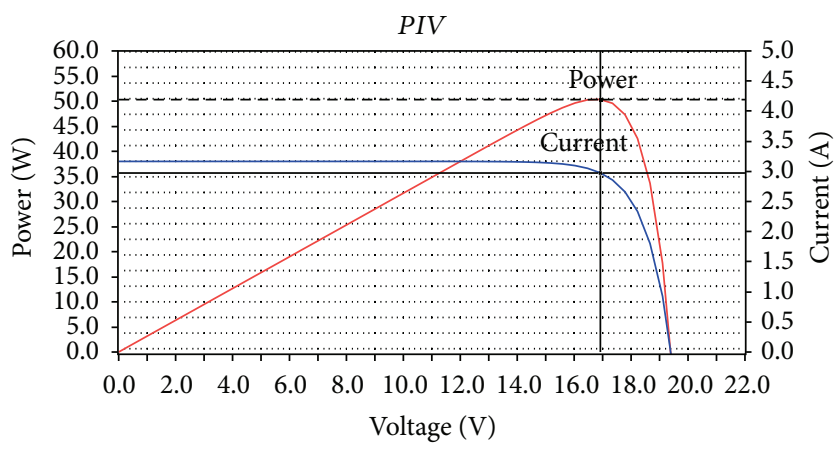

Figure 13: $I-V$ and $P-V$ curves for SX-50 Solarex PV panel when $T$ $=25^{\circ} \mathrm{C}$ and $S=1000 \mathrm{~W} / \mathrm{m}^{2}$ in LabVIEW.

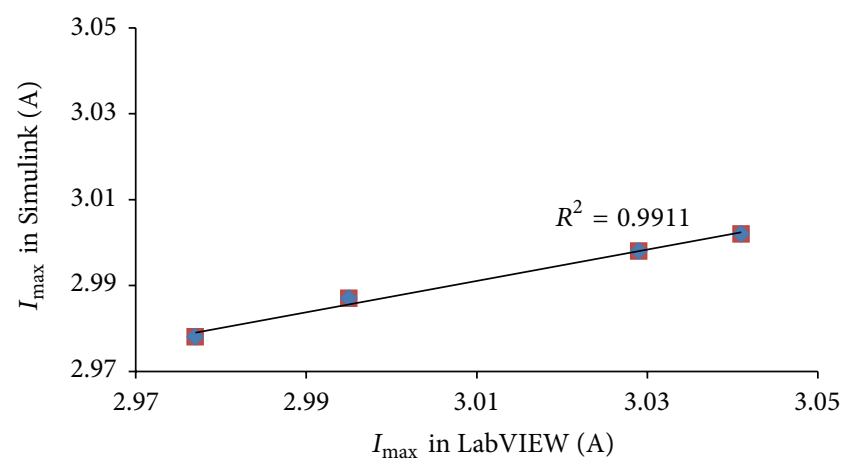

FIGURE 14: Schematic comparison of the values of $I_{\max }$ in Simulink and LabVIEW for $\mathrm{T}=0^{\circ} \mathrm{C}, 25^{\circ} \mathrm{C}, 50^{\circ} \mathrm{C}$, and $75^{\circ} \mathrm{C}$.

illustrates the simulation model developed in Simulink while Figure 9 depicts the same model built in LabVIEW.

4.3. Modeling of an Integrated PV System with Connection to Low-Voltage Grid. The third modelling task performed refers to the model development and performance analysis of a typical integrated PV system, having the structure shown in Figure 7, which is connected to low-voltage grid by using either a low load $(1.5 \mathrm{KW})$ or high load (6.5 KW).

The filter incorporated in the overall system structure is an LC circuit aiming to cut off the range of the output current which produces the DC-AC inverter harmonic frequencies.

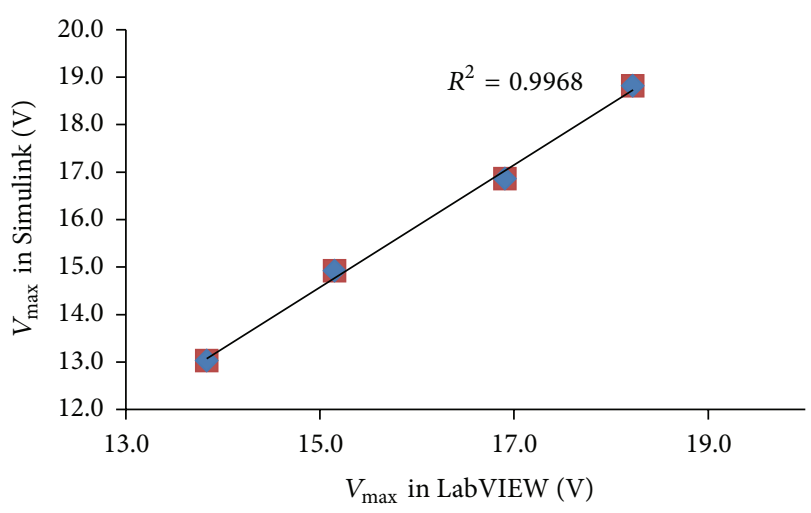

FIGURE 15: Schematic comparison of the values of $V_{\max }$ in Simulink and LabVIEW for $\mathrm{T}=0^{\circ} \mathrm{C}, 25^{\circ} \mathrm{C}, 50^{\circ} \mathrm{C}$, and $75^{\circ} \mathrm{C}$.

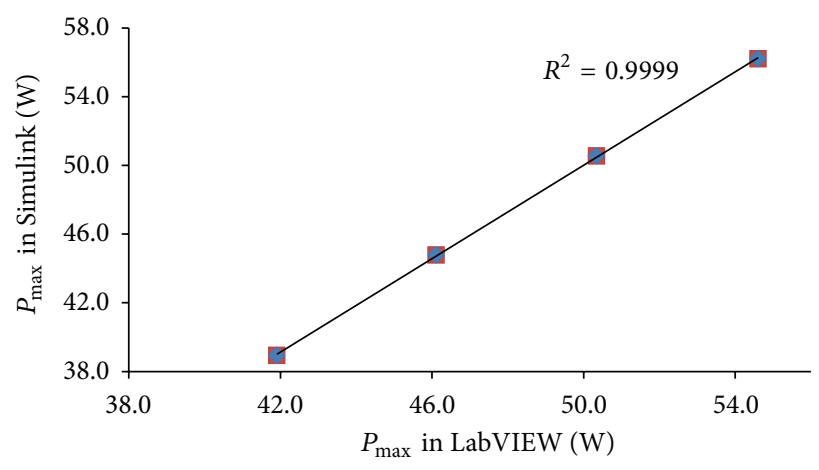

FIgURE 16: Schematic comparison of the values of $P_{\max }$ in Simulink and LabVIEW for $\mathrm{T}=0^{\circ} \mathrm{C}, 25^{\circ} \mathrm{C}, 50^{\circ} \mathrm{C}$, and $75^{\circ} \mathrm{C}$.

Similarly, an RL circuit was used in the line which connects the filter with the load. Figure 10 illustrates the simulation model developed in Simulink while Figure 11 depicts the same model built in LabVIEW.

\section{Simulation Results and Discussion}

In the following subsections of Section 5 the outcomes of the simulation tests carried out are both described and commented on. 


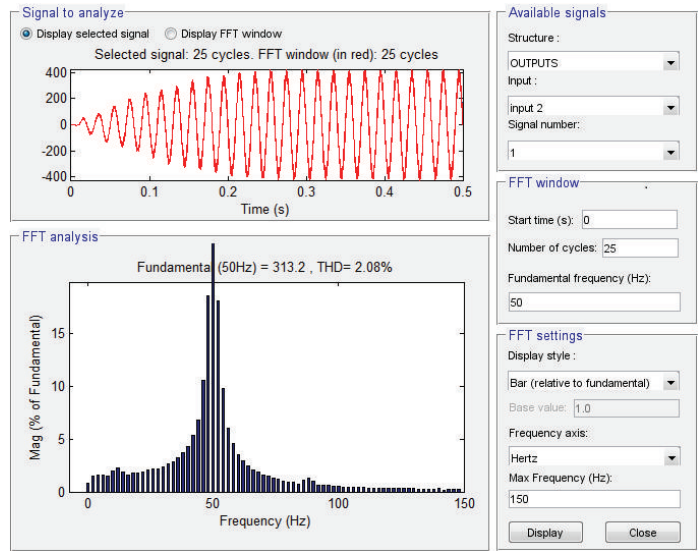

FIGURE 17: Voltage at load with no grid connection in Simulink.

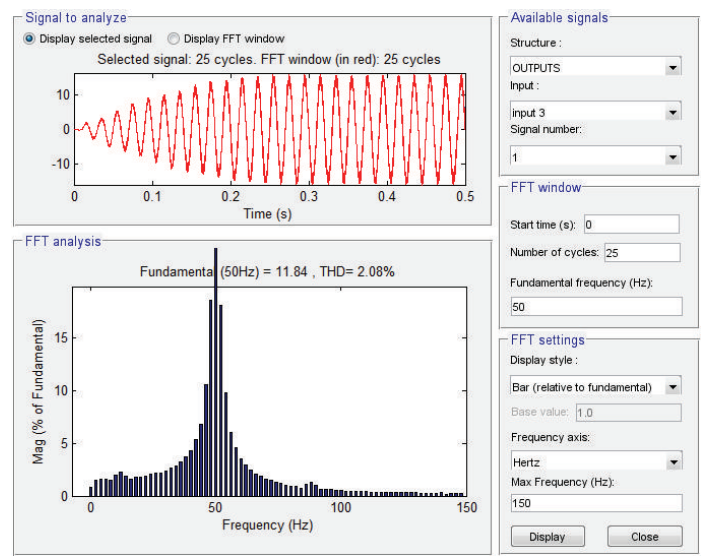

FIGURE 18: Current at load with no grid connection in Simulink.

TABLE 2: Simulation results for $I_{\max }, V_{\max }$, and $P_{\max }\left(T=0^{\circ} \mathrm{C}\right)$.

\begin{tabular}{lccc}
\hline & $I_{\max }(\mathrm{A})$ & $V_{\max }(\mathrm{V})$ & $P_{\max }(\mathrm{W})$ \\
\hline Simulink & 2.995 & 18.226 & 54.607 \\
LabVIEW & 2.987 & 18.811 & 56.198 \\
\hline
\end{tabular}

5.1. Performance Evaluation of the PV Panel Modeled. The basic assumption in all simulations tests carried out for the performance analysis of the solar panel modeled in Section 4.1 was that there was constant solar irradiance $S$ equal to $1000 \mathrm{~W} / \mathrm{m}^{2}$, while operation temperature $T$ was sequentially set to $0^{\circ} \mathrm{C}, 25^{\circ} \mathrm{C}, 50^{\circ} \mathrm{C}$, and $75^{\circ} \mathrm{C}$. For each one of these temperature values the corresponding $I-V$ and $P-V$ curves were drawn and the values of $I_{\max }, V_{\max }$ and $P_{\max }$ were calculated both in Simulink and LabVIEW. Indicatively, Figures 12 and 13 depict these curves for $T=25^{\circ} \mathrm{C}$ in Simulink and LabVIEW.

The values of $I_{\max }, V_{\max }$, and $P_{\max }$ which were found based on the simulation results in Simulink and LabVIEW for $T=$ $0^{\circ} \mathrm{C}$ are presented in Table 2. The corresponding results for $T$ $=50^{\circ} \mathrm{C}$ are presented in Table 3 and for $T=75^{\circ} \mathrm{C}$ in Table 4.

In a similar way, in Table 5, the values of $I_{\max }, V_{\max }$, and $P_{\max }$ calculated through the simulation results by using
TABLE 3: Simulation results for $I_{\max }, V_{\max }$, and $P_{\max }\left(T=50^{\circ} \mathrm{C}\right)$.

\begin{tabular}{lccc}
\hline & $I_{\max }(\mathrm{A})$ & $V_{\max }(\mathrm{V})$ & $P_{\max }(\mathrm{W})$ \\
\hline Simulink & 3.002 & 14.916 & 44.782 \\
LabVIEW & 3.041 & 15.152 & 46.108 \\
\hline
\end{tabular}

TABLE 4: Simulation results for $I_{\max }, V_{\max }$, and $P_{\max }\left(T=75^{\circ} \mathrm{C}\right)$.

\begin{tabular}{lccc}
\hline & $I_{\max }(\mathrm{A})$ & $V_{\max }(\mathrm{V})$ & $P_{\max }(\mathrm{W})$ \\
\hline Simulink & 2.998 & 13.024 & 38.925 \\
LabVIEW & 3.029 & 13.834 & 41.91 \\
\hline
\end{tabular}

TABLE 5: Simulation results for $I_{\max }, V_{\max }$, and $P_{\max }\left(T=25^{\circ} \mathrm{C}\right)$.

\begin{tabular}{lccc}
\hline & $I_{\max }(\mathrm{A})$ & $V_{\max }(\mathrm{V})$ & $P_{\max }(\mathrm{W})$ \\
\hline Simulink & 2.998 & 16.86 & 50.55 \\
LabVIEW & 2.977 & 16.909 & 50.344 \\
Solarex & 2.97 & 16.8 & 50 \\
\hline
\end{tabular}

TABle 6: Percentage deviation between default values and simulation results for $I_{\max }, V_{\max }$, and $P_{\max }\left(T=25^{\circ} \mathrm{C}\right)$.

\begin{tabular}{lccc}
\hline & $I_{\max }(\%)$ & $V_{\max }(\%)$ & $P_{\max }(\%)$ \\
\hline Simulink & +0.951 & +0.357 & +1.1 \\
LabVIEW & +0.247 & +0.648 & +0.688 \\
\hline
\end{tabular}

Simulink and LabVIEW for $T=25^{\circ} \mathrm{C}$ are presented against the corresponding values provided by the manufacturer of the PV panel, that is, Solarex [32].

The percentage deviation of the simulation data of $I_{\max }$, $V_{\max }$, and $P_{\max }$ from the corresponding dfault values provided by Solarex is shown in Table 6 .

The evaluation of the correlation existing between the simulation results attained alternatively via Simulink and LabVIEW for $I_{\max }, V_{\max }$, and $P_{\max }$ is obtained through the calculation of the coefficient of determination $\left(R^{2}\right)$. As shown in Figures 14, 15, and 16 the values of $R^{2}$ found correspondingly for $I_{\max }, V_{\max }$, and $P_{\max }$ are equal to 0.989 , 0.996 , and 0.999 .

5.2. Performance Evaluation of an Integrated PV System with No Grid Connection. The performance analysis of the integrated PV described in Section 4.2 was carried out by the investigation of specific characteristics of the system, that is, the system output voltage at load and the current at load by performing Fourier transformation. Simulink makes use of the so-called Powegui FFT Analysis tool which enables the implementation of fast Fourier transformation of signals. Similarly, LabVIEW makes use of STARSIM which is an electrical system simulation tool.

The results of the simulation of these two features in Simulink are depicted in Figures 17 and 18.

By applying fast Fourier transformation, it was found that the total harmonic distortion at load is $2.08 \%$, while the amplitude of the voltage at the fundamental frequency is $313.2 \mathrm{~V}$ and the amplitude of the current at the fundamental frequency is $11.84 \mathrm{~A}$. 


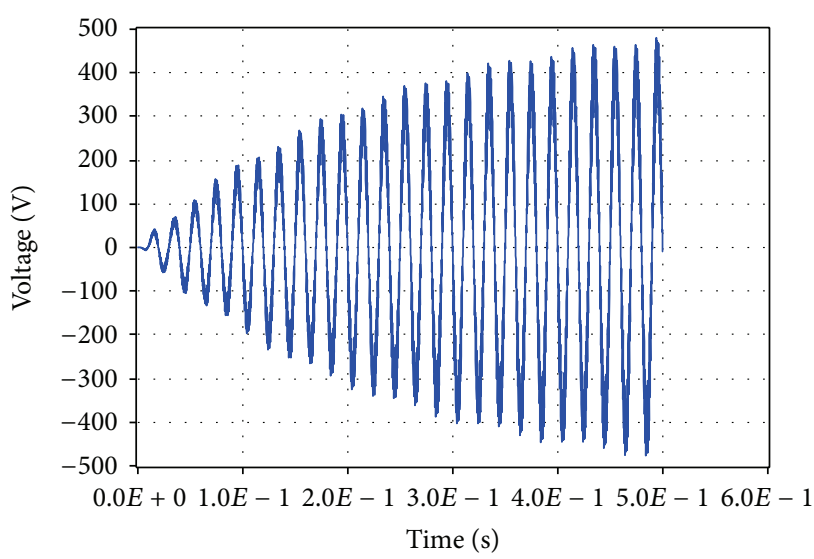

(a)

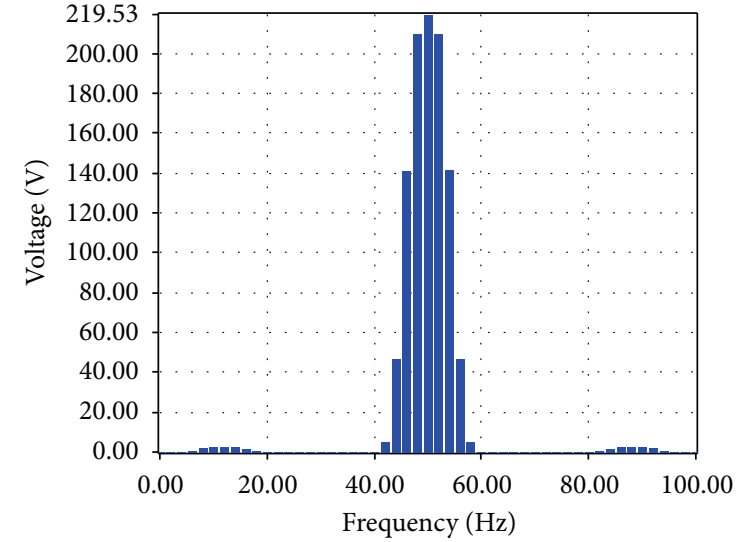

(b)

FIGURE 19: Voltage at load with no grid connection in LabVIEW.

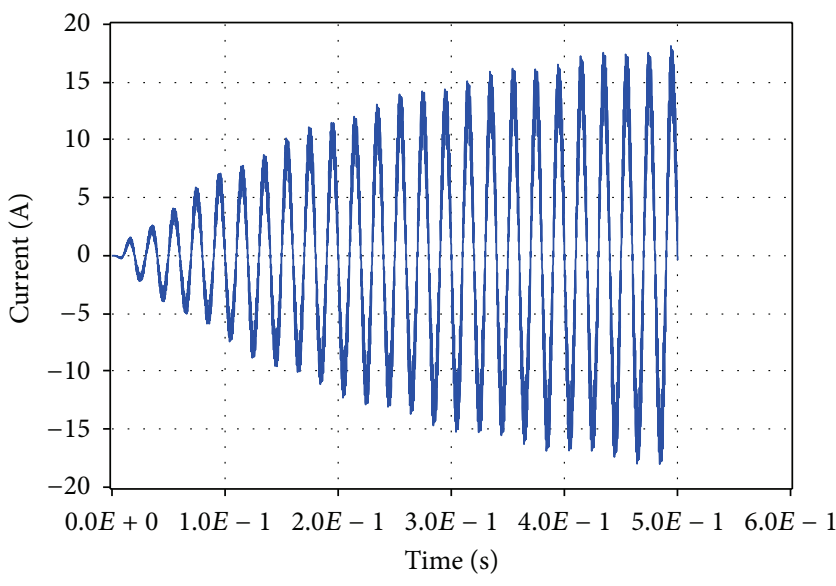

(a)

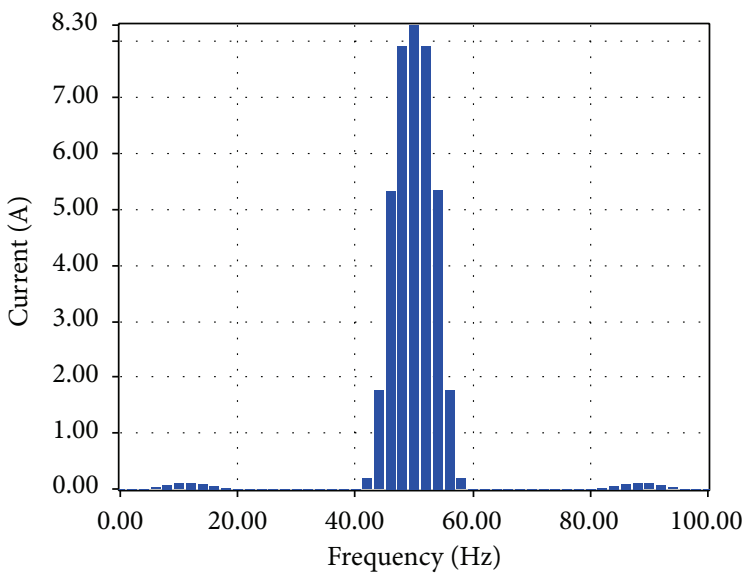

(b)

FIGURE 20: Current at load with no grid connection in LabVIEW.

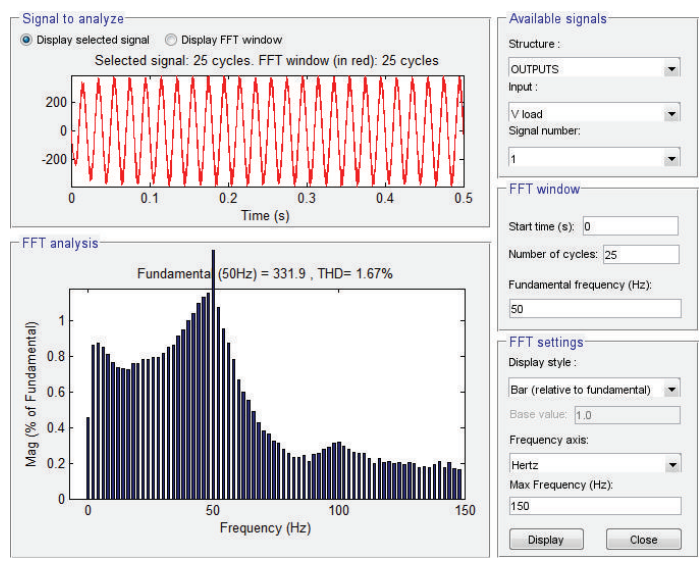

FIGURE 21: Voltage at load 1.5 KW with grid connection in Simulink.

The corresponding simulation results in LabVIEW proved that the total harmonic distortion at load is $3.78 \%$,

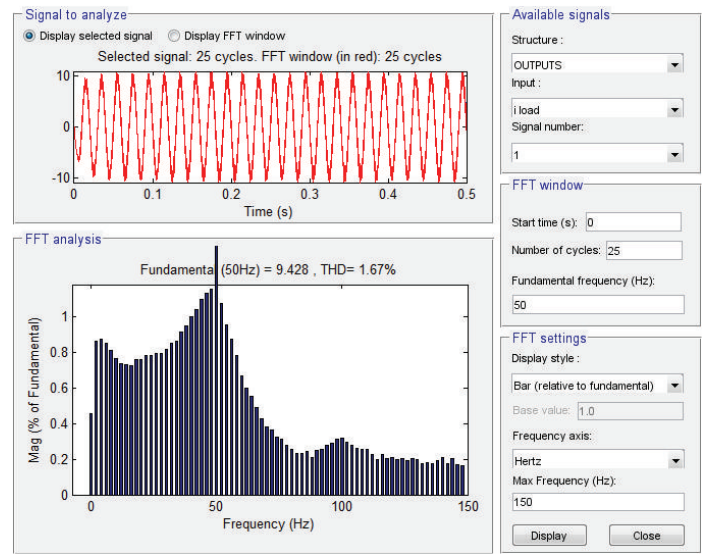

FIgURE 22: Current at load 1.5 KW with grid connection in Simulink.

while the amplitude of the voltage at the fundamental frequency is $219.53 \mathrm{~V}$ RMS, that is, $310.46 \mathrm{~V}$, and the amplitude of 


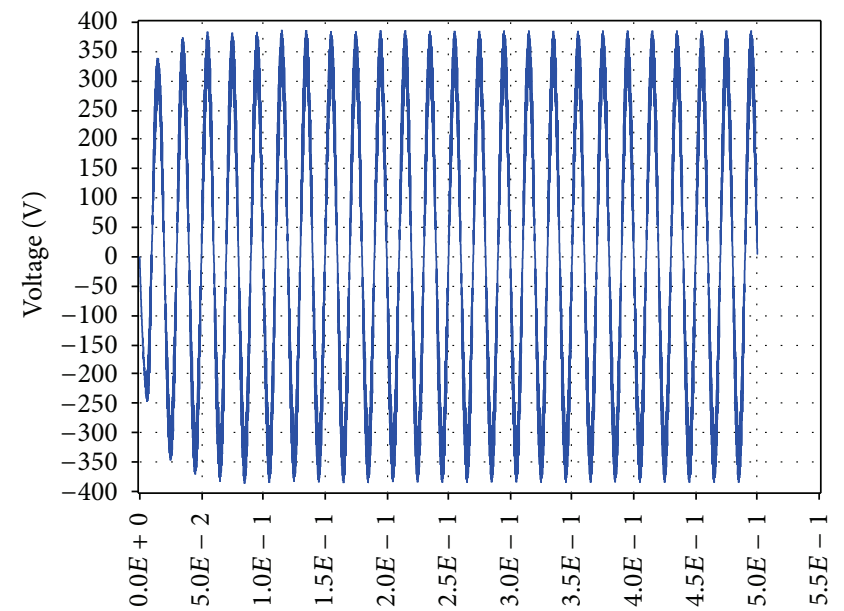

Time (s)

(a)

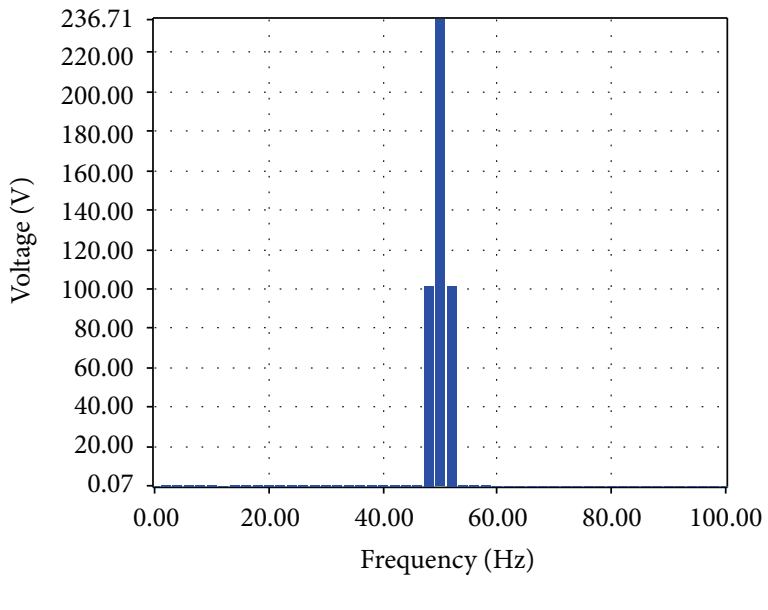

(b)

FIGURE 23: Voltage at load $1.5 \mathrm{KW}$ with grid connection in LabVIEW.

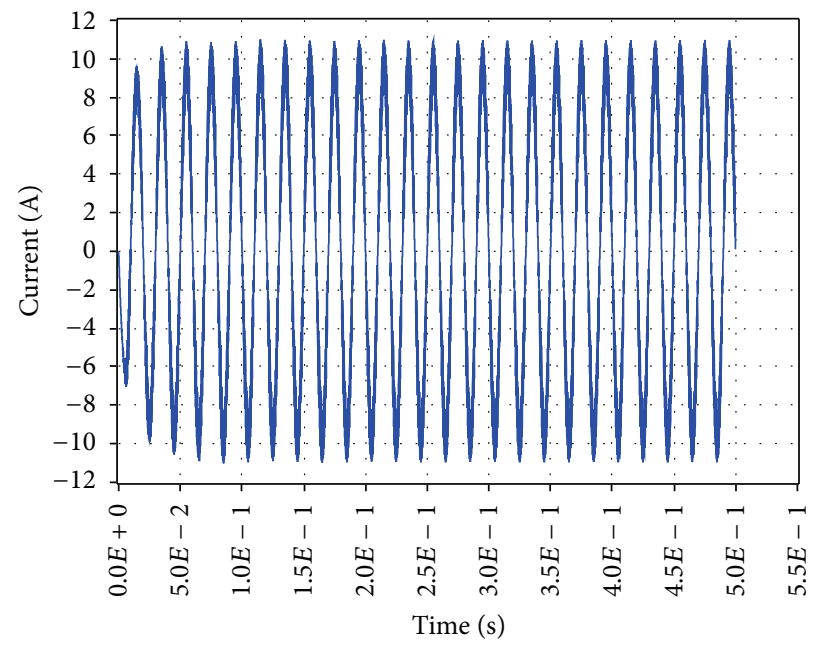

(a)

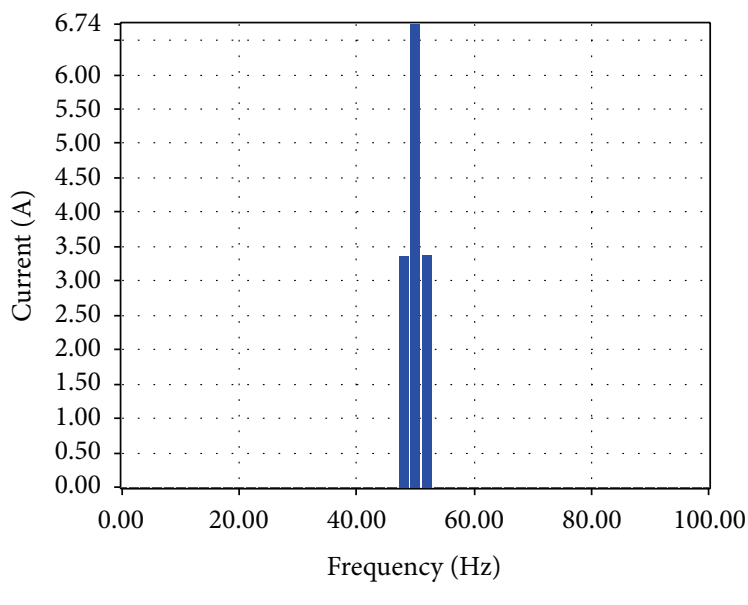

(b)

FIGURE 24: Current at load 1.5 KW with grid connection in LabVIEW.

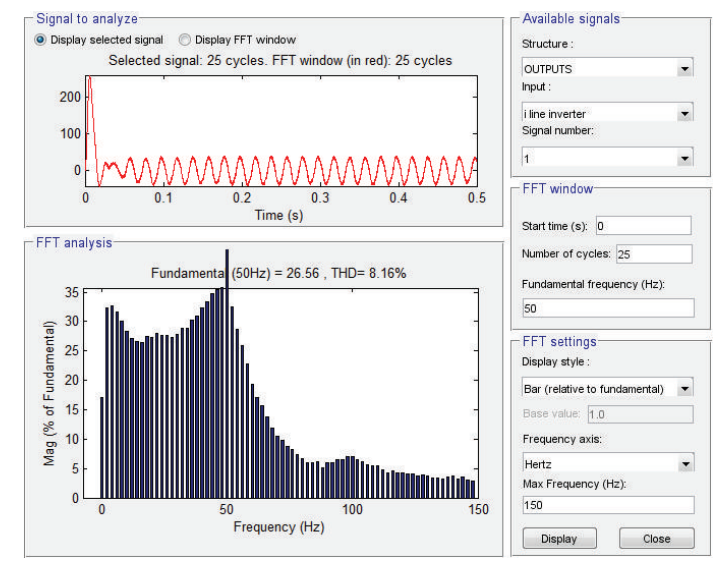

Figure 25: Current to load 1.5 KW and network with grid connection in Simulink. 


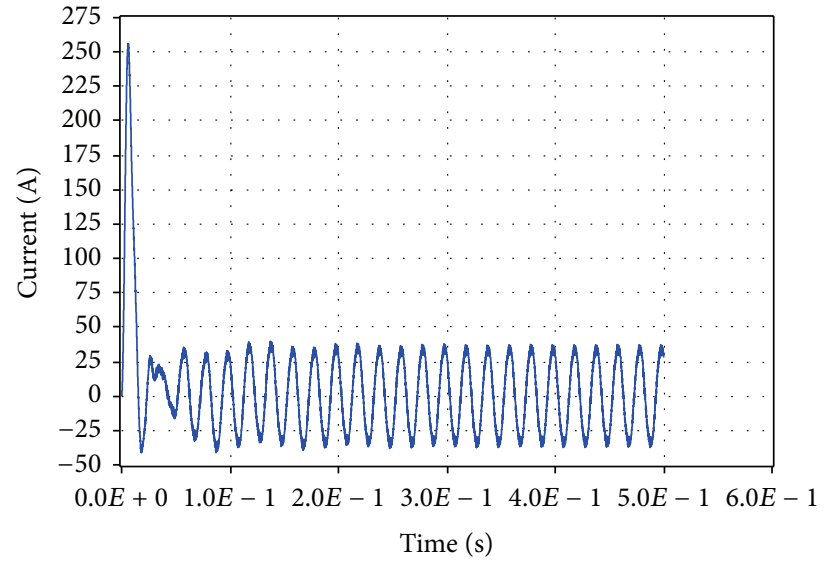

(a)

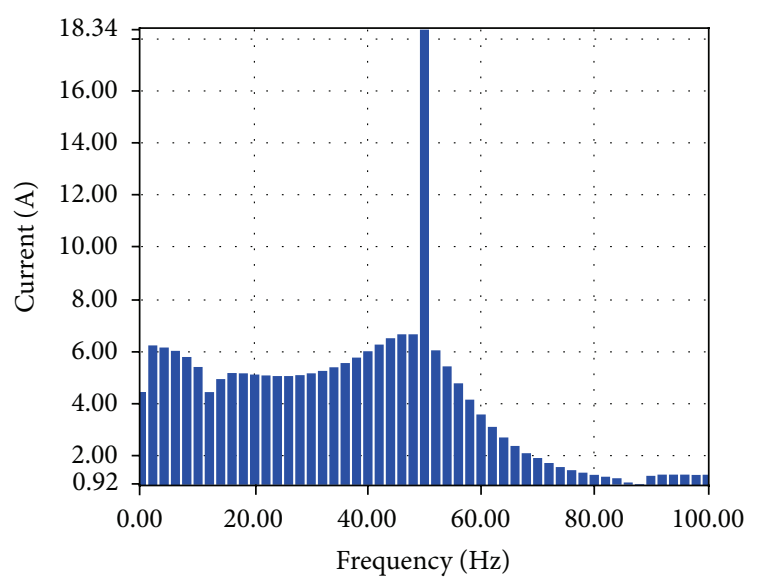

(b)

FIgURE 26: Current to load 1.5 KW and network with grid connection in LabVIEW.

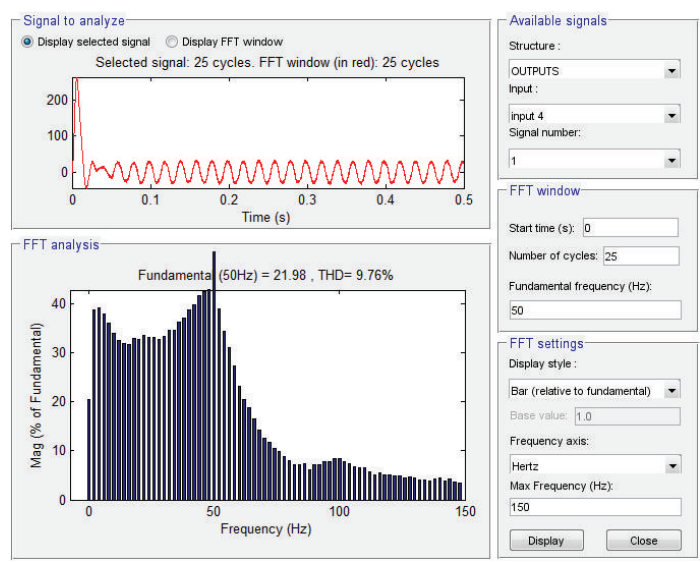

FIGURE 27: Current to network with grid connection and load $1.5 \mathrm{KW}$ in Simulink.

the current at the fundamental frequency is $8.3 \mathrm{~A}$ RMS, that is, $11.74 \mathrm{~A}$, as shown correspondingly in Figures 19 and 20.

The comparison of these data shows that the simulation through Simulink and LabVIEW leads to results which have a percentage deviation less than $0.9 \%$ for both voltage at load and current at load.

5.3. Performance Evaluation of an Integrated PV System with Connection to Low-Voltage Grid. By using the same software tools as in the last subsection, the performance analysis of the, described in Section 4.3, integrated PV connected to lowvoltage grid was carried out.

First, the low load $(1.5 \mathrm{KW})$ case was examined, starting with the output voltage at load and current at load. The subsequent simulation results via Simulink are shown in Figures 21 and 22, respectively.

Based on these plots it was found that the total harmonic distortion at load is $1.67 \%$, while the amplitude of the voltage at load at the fundamental frequency is $331.9 \mathrm{~V}$ and the amplitude of the current at the fundamental frequency is $9.428 \mathrm{~A}$.

The corresponding simulation results in LabVIEW proved that the amplitude of the voltage at the fundamental frequency is $236.71 \mathrm{~V}$ RMS, that is, $334.76 \mathrm{~V}$, and the amplitude of the current at the fundamental frequency is $6.74 \mathrm{~A}$ RMS, that is, $9.53 \mathrm{~A}$, while the total harmonic distortion at load is $11.25 \%$ as shown correspondingly in Figures 23 and 24.

Similarly, the total current at the connection of the system to the load and network was investigated. The resultant simulation plots drawn through the alternative utilization of Simulink and LabVIEW are depicted in Figures 25 and 26, respectively.

Based on these plots it was found that according to Simulink the amplitude of the total current at the connection of the system to the load and network is equal to $26.56 \mathrm{~A}$ while the total harmonic distortion is equal to $8.16 \%$. The corresponding simulation results in LabVIEW proved that the current amplitude is equivalent to $18.34 \mathrm{~A}$ RMS, that is, $25.94 \mathrm{~A}$, while THD is $6.65 \%$.

Similarly, the current at the connection of the system to the network was examined. The resultant simulation plots via Simulink and LabVIEW are depicted in Figures 27 and 28 , respectively. Based on these plots it was found that according to Simulink the amplitude of the total current at the connection to the network is equal to $21.98 \mathrm{~A}$ while the total harmonic distortion is equal to $9.76 \%$. The corresponding simulation results in LabVIEW proved that the current amplitude is equivalent to $15.02 \mathrm{~A}$ RMS, that is, $21.24 \mathrm{~A}$, while THD is $6.84 \%$.

The comparative examination of the aforementioned simulation results regarding the $1.5 \mathrm{KW}$ load case shows that the percentage deviation between Simulink and LabVIEW is equal to $0.85 \%$ for the voltage at load, $1.07 \%$ for the current at load, $2.33 \%$ for the total current to load and network, and $3.44 \%$ for the current to network.

Finally, the high load $(6.5 \mathrm{KW})$ case was examined, starting with the output voltage at load and current at load. 


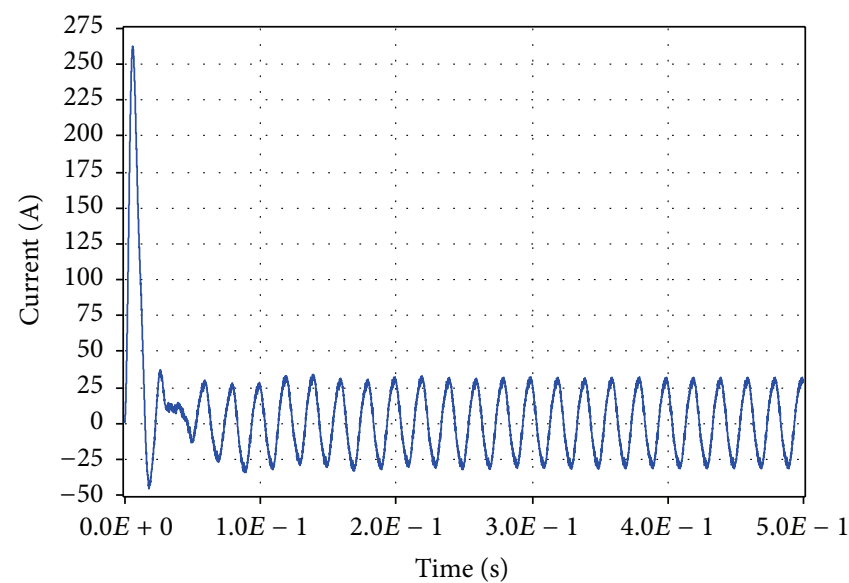

(a)

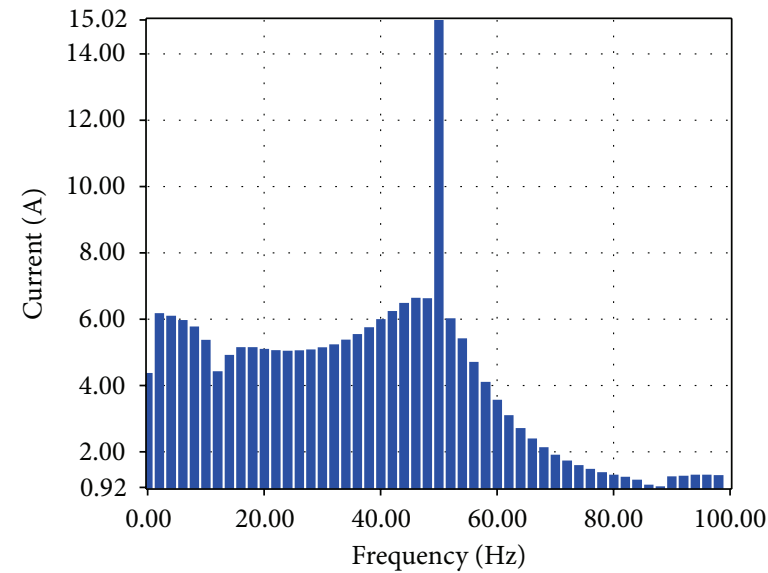

(b)

FIGURE 28: Current to network with grid connection and load 1.5 KW in LabVIEW.

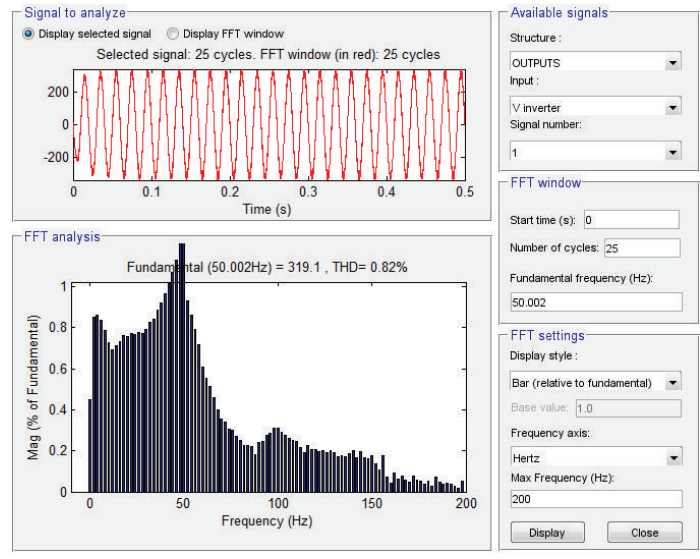

FIGURE 29: Voltage at load 6.5 KW with grid connection in Simulink.

The subsequent simulation results via Simulink are shown in Figures 29 and 30, respectively.

Based on these plots it was found that the amplitude of the voltage at load at the fundamental frequency is $319.1 \mathrm{~V}$, and the amplitude of the current at the fundamental frequency is $39.89 \mathrm{~A}$, while the total harmonic distortion at load is $0.82 \%$. The equivalent results in LabVIEW proved that the amplitude of the voltage at the fundamental frequency is $227.95 \mathrm{~V}$ RMS, that is, $322.37 \mathrm{~V}$, and the amplitude of the current at the fundamental frequency is $28.49 \mathrm{~A}$ RMS, that is, 40.29 A while the total harmonic distortion at load is $7.83 \%$, as shown correspondingly in Figures 31 and 32.

Similarly, the total current at the connection of the system to the load and network was investigated. The resultant simulation plots via Simulink and LabVIEW are depicted in Figures 33 and 34, respectively.

Based on these plots it was found that according to Simulink the amplitude of the total current at the connection of the system to the load and network is equal to $19.76 \mathrm{~A}$ while the total harmonic distortion is equal to $9.88 \%$. The corresponding simulation results in LabVIEW proved that

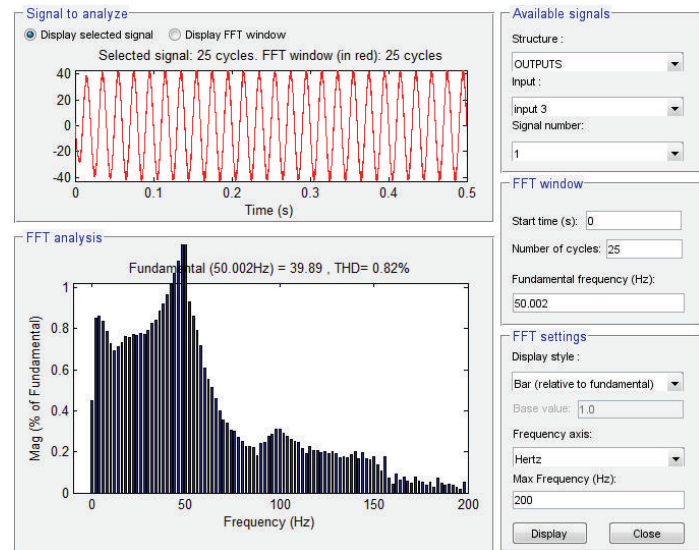

FIgure 30: Current at load $6.5 \mathrm{KW}$ with grid connection in Simulink.

the current amplitude is equivalent to $13.99 \mathrm{~A}$ RMS, that is, $19.78 \mathrm{~A}$, while THD is $11.54 \%$.

Similarly, the current at the connection of the system to the network was examined. The resultant simulation plots via Simulink and LabVIEW are depicted in Figures 35 and 36, respectively.

Based on these plots it was found that according to Simulink the amplitude of the total current at the connection to the network is equal to $23.53 \mathrm{~A}$ while the total harmonic distortion is equal to $7.89 \%$. The corresponding simulation results in LabVIEW proved that the current amplitude is equivalent to $16.38 \mathrm{~A}$, RMS that is, $23.16 \mathrm{~A}$, while THD is $10.4 \%$.

The comparative examination of the aforementioned simulation results regarding the $6.5 \mathrm{KW}$ load case shows that the percentage deviation between Simulink and LabVIEW is equal to $1.0 \%$ for the voltage at load, $1.0 \%$ for the current at load, $0.1 \%$ for the total current to load and network, and $1.57 \%$ for the current to network. 


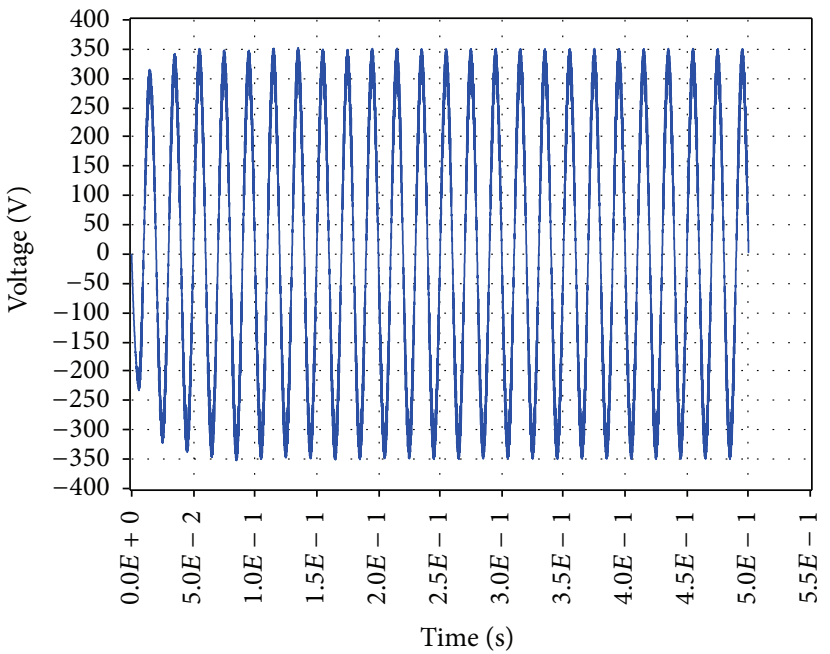

(a)

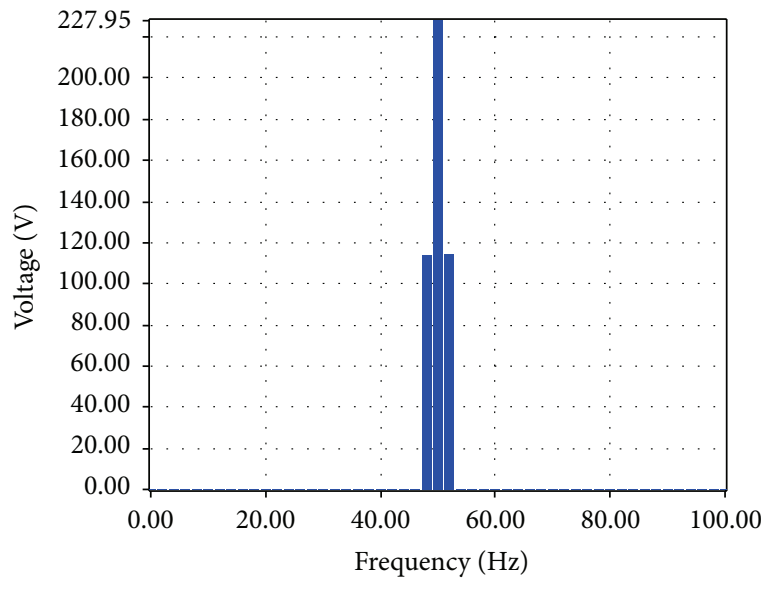

(b)

FIGURE 31: Voltage at load 6.5 KW with grid connection in LabVIEW.

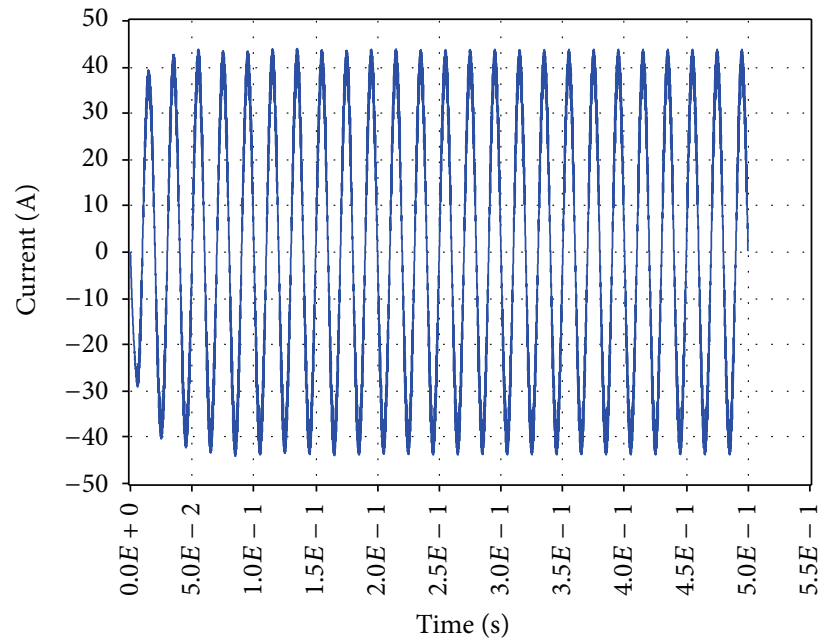

(a)

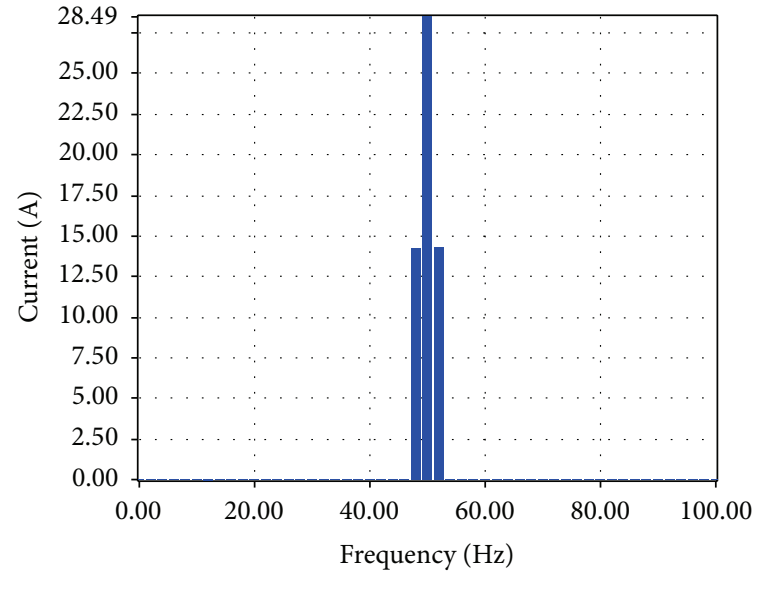

(b)

Figure 32: Current at load 6.5 KW with grid connection in LabVIEW.

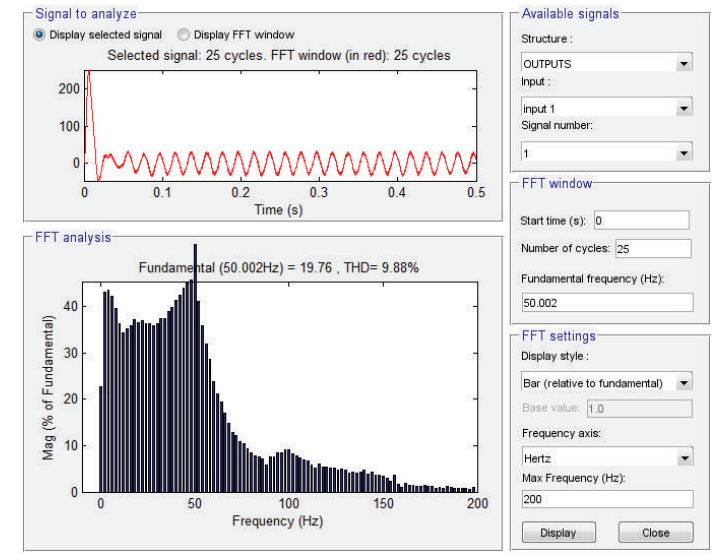

FIGURE 33: Current to load 6.5 KW and network with grid connection in Simulink. 


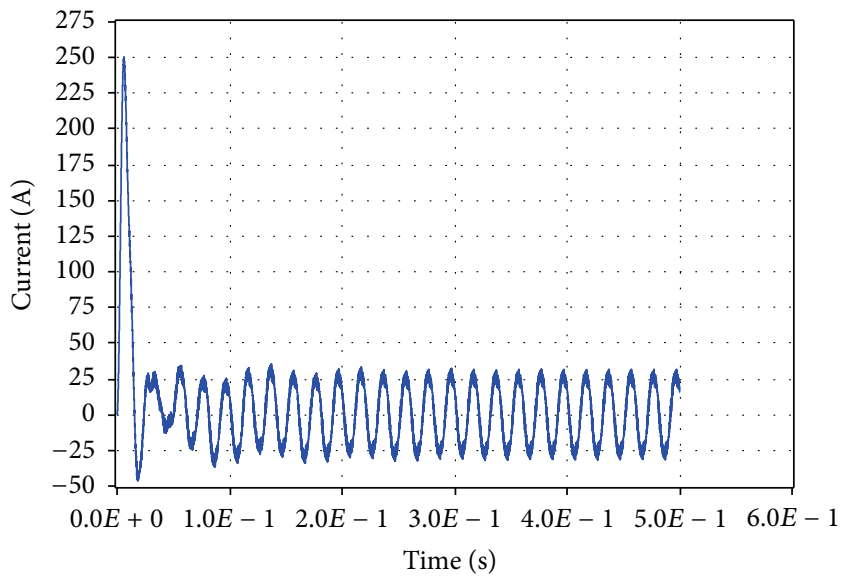

(a)

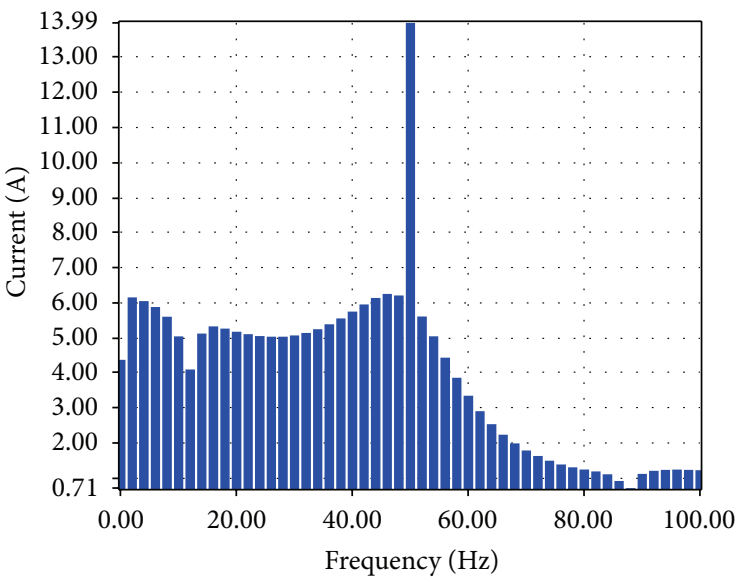

(b)

FIGURE 34: Current to load $6.5 \mathrm{KW}$ and network with grid connection in LabVIEW.

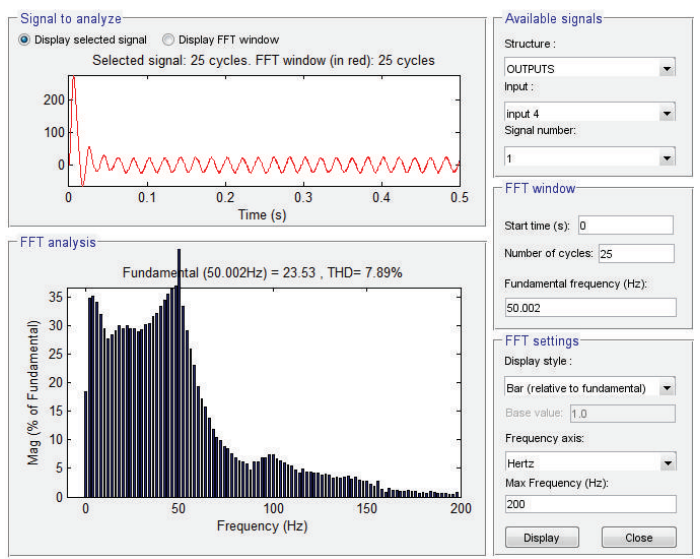

FIgURE 35: Current to network with grid connection and load 6.5 KW in Simulink.

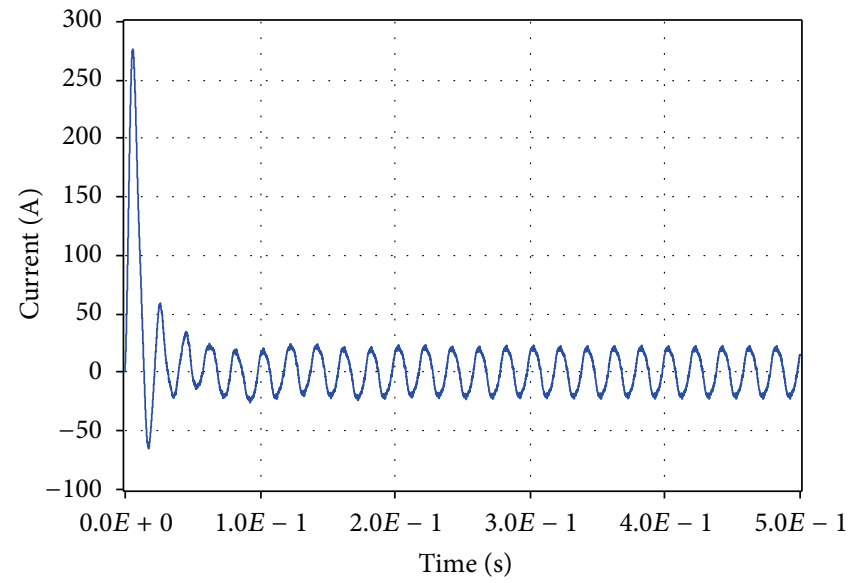

(a)

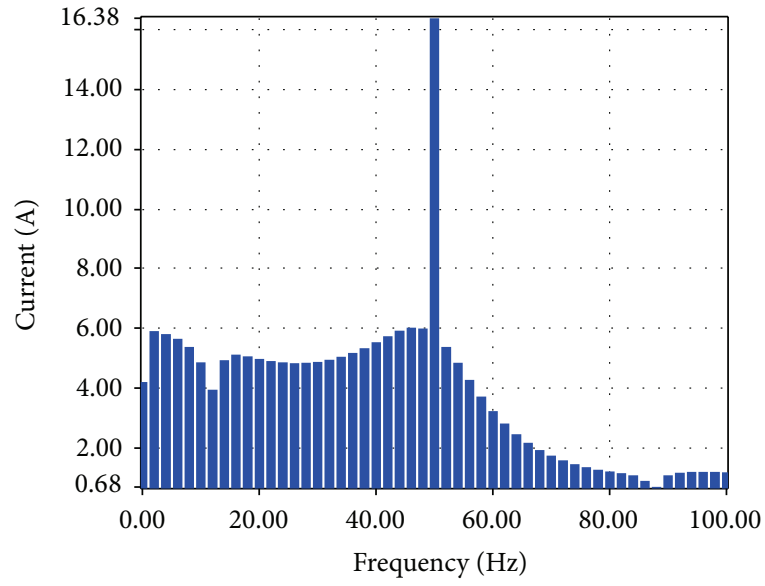

(b)

FIGURE 36: Current to network with grid connection and load $6.5 \mathrm{KW}$ in LabVIEW. 


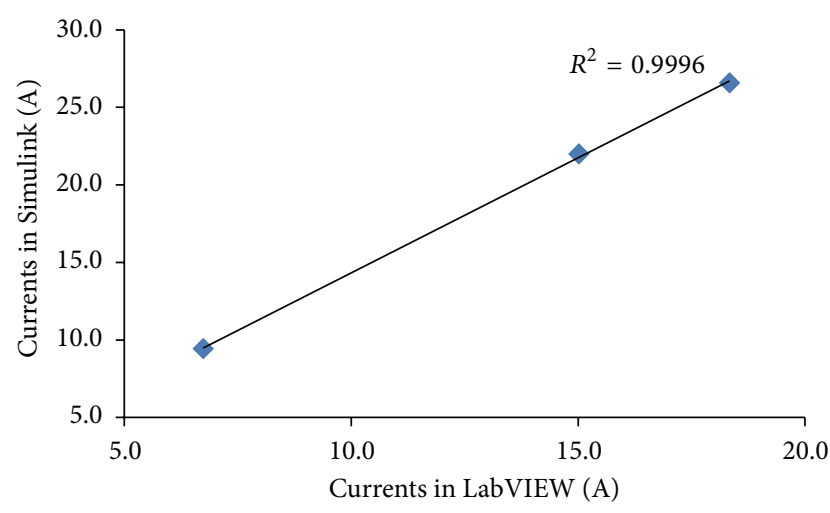

FIGURE 37: Coefficient of determination $R^{2}$ for the $1.5 \mathrm{KW}$ load case.

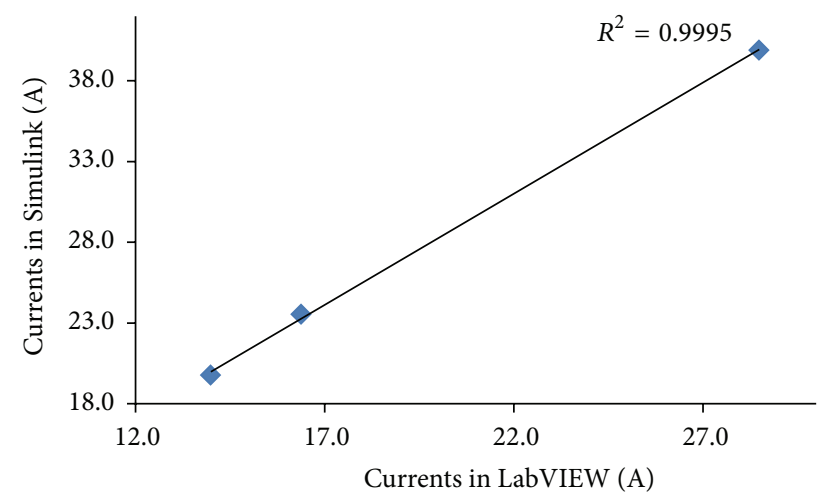

FIgURE 38: Coefficient of determination $R^{2}$ for the $6.5 \mathrm{KW}$ load case.

The correlation between the results attained via Simulink and LabVIEW for the performance simulation of the gridconnected integrated PV system can be synoptically evaluated in terms of the coefficient of determination $\left(R^{2}\right)$. For this reason $R^{2}$ was computed for both the low load and high load cases by taking into consideration the values of all current amplitudes which were calculated.

Specifically, in the $1.5 \mathrm{KW}$ case $R^{2}$ was found to be equal to 0.999 as shown in Figure 37. Similarly, in the $6.5 \mathrm{KW}$ case $R^{2}$ was found to be also equal to 0.999 as illustrated in Figure 38 .

\section{Conclusions}

The work presented in this paper focused on computeraided model development and performance analysis of photovoltaic systems. For this reason, suitable models were built for various formations of photovoltaic schemes. All tasks performed were based on the use of two advanced graphical programming environments, namely, Simulink and LabVIEW. In this way, a comparative evaluation of the credibility of these software platforms was carried out.

Specifically, the case of a commercially available PV panel was studied. A model representing this panel was built and its operation was simulated. The simulation results regarding its characteristic features were compared to those provided by the PV panel manufacturer. The results of this comparison were positive in terms of both the modelling performed and the convergence between the outcomes of the two programming environments.

Next, the model of an integrated PV system having no grid connection was built and the performance analysis of this system was carried out by applying fast Fourier transformation. The simulation tests performed showed that both software platforms provide results which are almost the same regarding the electric entities simulated and slightly different regarding the signal total harmonic distortion.

Finally, the case of an integrated photovoltaic system connected to low-voltage grid was examined. Once again the model development was followed by the overall system performance analysis by examining the cases having a relatively low load and alternatively a higher load connected to the network. The application of fast Fourier transformation provided again results which have a small deviation regarding the electric entities simulated and a bigger one regarding the total harmonic distortion of the signals, thus indicating the existence of different noise influence.

\section{Conflict of Interests}

The authors declare that there is no conflict of interests.

\section{References}

[1] M. Meinshausen, N. Meinshausen, W. Hare et al., "Greenhousegas emission targets for limiting global warming to 2०C," Nature, vol. 458, no. 7242, pp. 1158-1162, 2009.

[2] European Union, Climate Change: Commission Welcomes Final Adoption of Europe's Climate and Energy Package, Press Release, 2008.

[3] J. Twidell and T. Weir, Energy Resources, Taylor \& Francis, 2nd edition, 2012.

[4] A. V. Herzog, T. E. Lipman, and D. M. Kammen, Renewable Energy Sources, Encyclopedia of Life Support Systems (EOLSS), 2001.

[5] M. A. G. De Brito, L. P. Sampaio, L. G. Junior, and C. A. Canesin, "Research on photovoltaics: review, trends and perspectives," in Proceedings of the 11th Brazilian Power Electronics Conference (COBEP '11), pp. 531-537, September 2011.

[6] R. W. Miles, K. M. Hynes, and I. Forbes, "Photovoltaic solar cells: an overview of state-of-the-art cell development and environmental issues," Progress in Crystal Growth and Characterization of Materials, vol. 51, no. 1-3, pp. 1-42, 2005.

[7] K. Branker, M. J. M. Pathak, and J. M. Pearce, "A review of solar PV levelized cost of electricity," Renewable and Sustainable Energy Reviews, vol. 15, no. 9, pp. 4470-4482, 2011.

[8] N. Kehtarnavaz and C. Gope, "DSP system design using LabVIEW and Simulink: a comparative evaluation," in Proceedings of the IEEE International Conference on Acoustics, Speech and Signal Processing (ICASSP '06), pp. II985-II988, May 2006.

[9] A. Luque and S. Hegedus, Handbook of PV Science and Engineering, 2011.

[10] T. K. Carlsson, Experimental Set Up For Full Scale Field Test of CdTe and Cis Thin Film PV Modules, 2001.

[11] G. Makrides, B. Zinsser, M. Norton, and G. E. Georghiou, Performance of Photovoltaics Under Actual Operating Conditions, 2012. 
[12] R. E. Hanitsch, D. Schulz, and U. Siegfried, "Shading effects on output power of grid connected photovoltaic generator systems," Technical University Berlin, Institute of Electrical Power and Automation Technology. In press.

[13] A. Parrettaa, H. Yakubua, F. Ferrazzab, P. Altermatt, M. A. Green, and J. Zhao, "Optical loss of PV modules under diffuse light," Solar Energy Materials and Solar Cells, vol. 75, pp. 497505, 2003.

[14] G. T. Klise and J. S. Stein, Models Used To Assess the Performance of PV Systems, Sandia National Laboratories, 2009.

[15] I. H. Altas and A. M. Sharaf, "A photovoltaic array simulation model for matlab-simulink GUI environment," in Proceedings of the International Conference on Clean Electrical Power (ICCEP '07), pp. 341-345, May 2007.

[16] T. DenHerder, Design and simulation of PV super system using Simulink [Ph.D. thesis], California Polytechnic State University, 2006.

[17] I. V. Banu and M. Istrate, "Modelling and simulation of PV arrays," Buletinul AGIR, vol. 3, pp. 161-166, 2012.

[18] A. D. Hansen, P. Sørensen, L. H. Hansen, and H. Bindner, Models For A Stand-Alone PV System, 2001.

[19] S.-K. Kim, J.-H. Jeon, C.-H. Cho, E.-S. Kim, and J.-B. Ahn, "Modeling and simulation of a grid-connected PV generation system for electromagnetic transient analysis," Solar Energy, vol. 83, no. 5, pp. 664-678, 2009.

[20] W. De Soto, S. A. Klein, and W. A. Beckman, "Improvement and validation of a model for PV array performance," Solar Energy, vol. 81, no. 1, p. 150, 2007.

[21] H. L. Tsai, C. S. Tu, and Y. J. Su, "Development of Generalized PV Model Using MATLAB/Simulink," in Proceedings of the World Congress on Engineering and Computer Science (WCECS '08), pp. 846-851, 2008.

[22] N. Pandiarajan and R. Muthu, "Mathematical modeling of photovoltaic module with Simulink," in Proceedings of the 1st International Conference on Electrical Energy Systems (ICEES '11), pp. 258-263, January 2011.

[23] K. Ishaque, Z. Salam, and H. Taheri, "Simple, fast and accurate two-diode model for photovoltaic modules," Solar Energy Materials and Solar Cells, vol. 95, no. 2, pp. 586-594, 2011.

[24] J. Muñoz and P. Díaz, "A virtual photovoltaic power systems laboratory," in Proceedings of the IEEE Education Engineering Conference (EDUCON '10), pp. 1737-1740, April 2010.

[25] M. Zahran, Y. Atia, A. Al-Hussain, and I. El-Sayed, "LabVIEW based monitoring system applied for PV power station," in Proceedings of the 12th WSEAS International Conference on Automatic Control, Modelling and Simulation (ACMOS '10), pp. 65-70, May 2010.

[26] Y. T. Tan, D. S. Kirschen, and N. Jenkins, "A model of PV generation suitable for stability analysis," IEEE Transactions on Energy Conversion, vol. 19, no. 4, pp. 748-755, 2004.

[27] A. Kajihara and T. Harakawa, "Model of photovoltaic cell circuits under partial shading," in Proceedings of the IEEE International Conference on Industrial Technology (ICIT '05), pp. 866-870, December 2005.

[28] K. Khouzam, C. Ly, C. K. Koh, and P. Y. Ng, "Simulation and real-time modelling of space photovoltaic systems," in Proceedings of the 24th IEEE Photovoltaic Specialists Conference, pp. 2038-2041, December 1994.

[29] R. Chenni, M. Makhlouf, T. Kerbache, and A. Bouzid, "A detailed modeling method for photovoltaic cells," Energy, vol. 32, no. 9, pp. 1724-1730, 2007.
[30] M. Chegaar, Z. Ouennoughi, and A. Hoffmann, "New method for evaluating illuminated solar cell parameters," Solid-State Electronics, vol. 45, no. 2, pp. 293-296, 2001.

[31] D. Sera, R. Teodorescu, and P. Rodriguez, "PV panel model based on datasheet values," in Proceedings of the IEEE International Symposium on Industrial Electronics (ISIE '07), pp. 23922396, June 2007.

[32] SX-40 SX-50 Photovoltaic Modules, 1999, Solarex, Maryland, USA, 6 pages, http://www.trichord-inc.com/pricing/frames/ content/solar_power.pdf. 


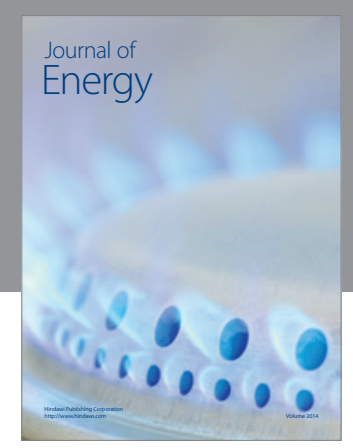

Journal of

Industrial Engineering
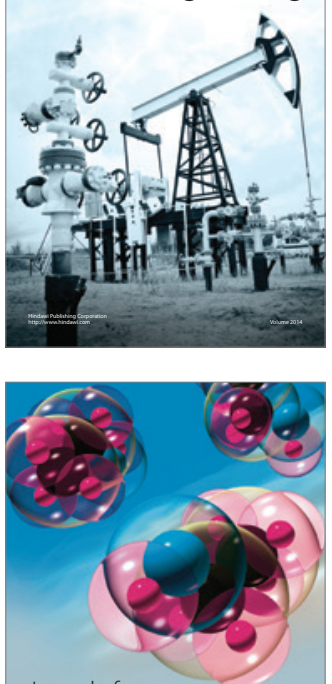

Fuels
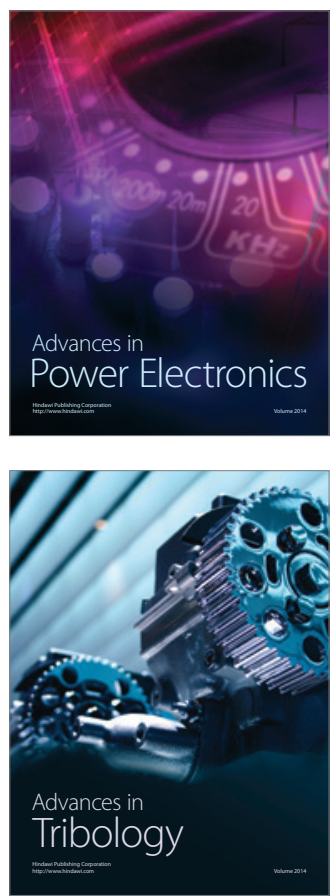

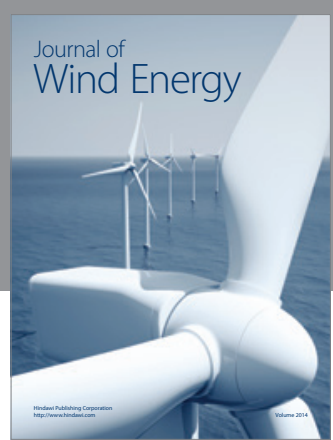

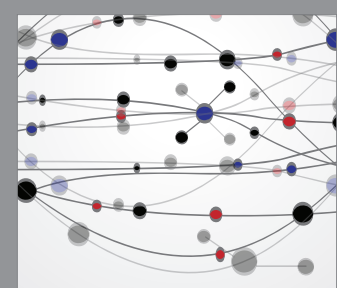

The Scientific World Journal

Submit your manuscripts at http://www.hindawi.com

Journal of

Structures
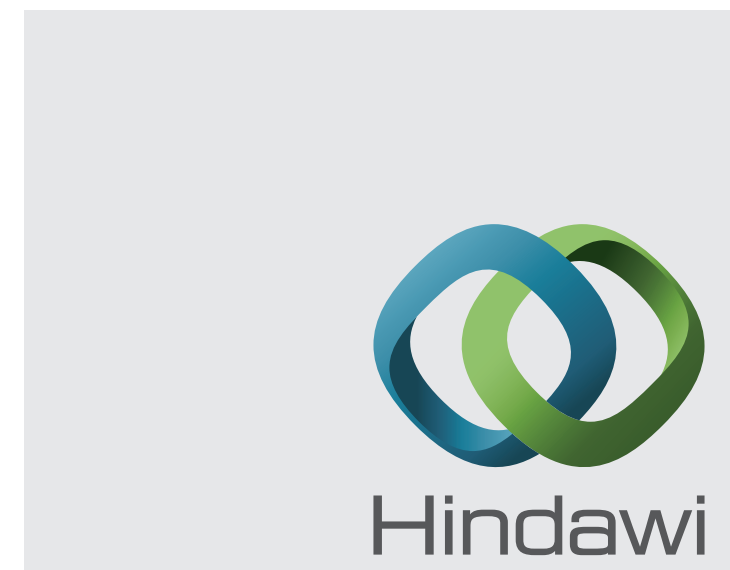

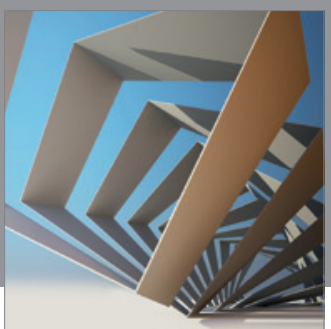

Rotating

Machinery
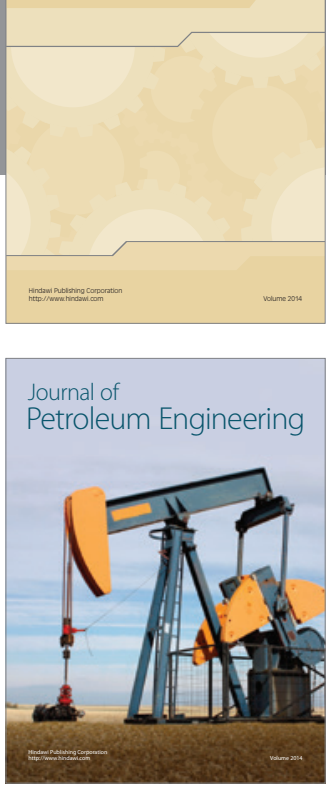

Journal of

Solar Energy
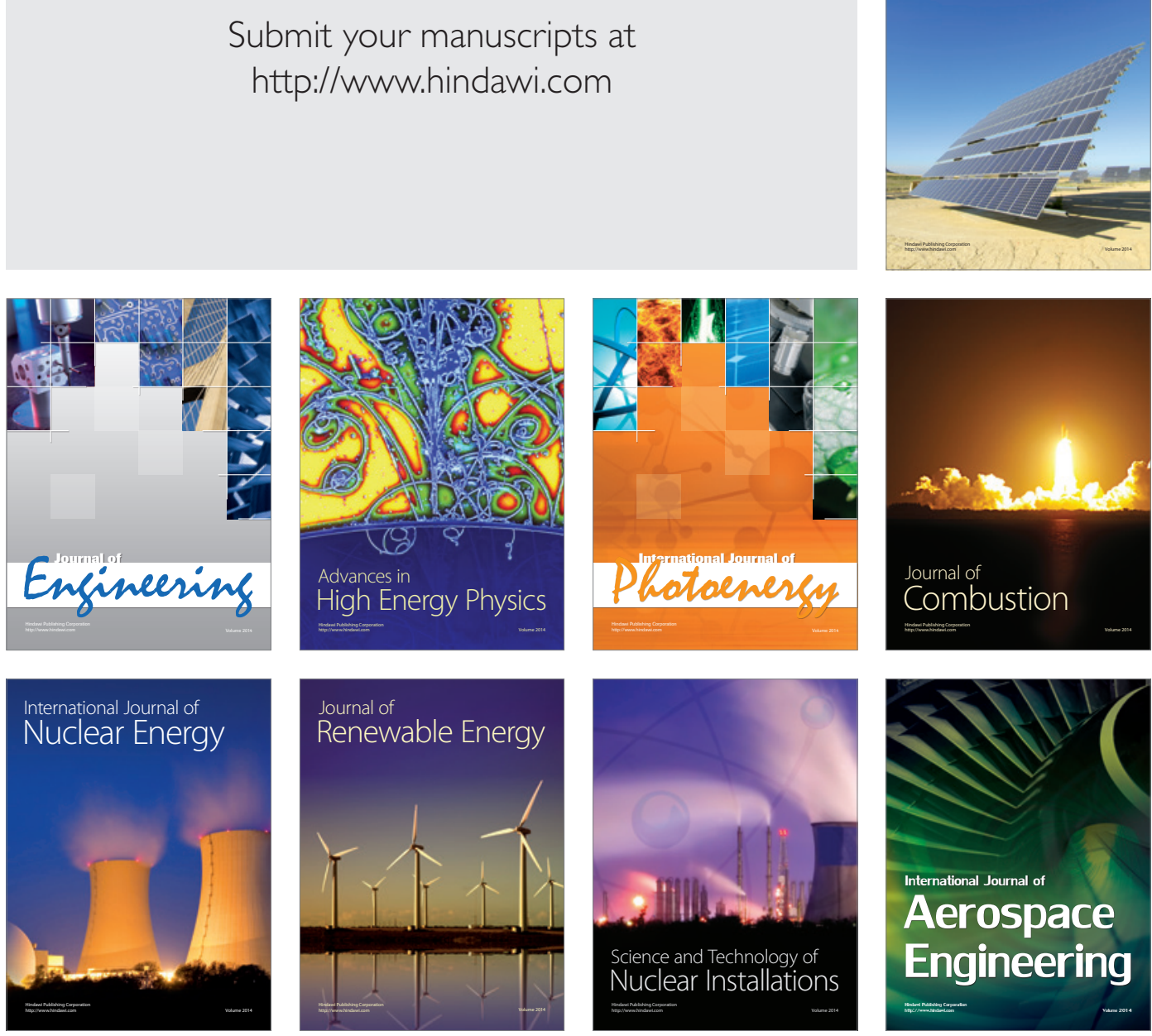